\title{
A novel retrieval of daytime atmospheric dust and volcanic ash heights through a synergy of AIRS infrared radiances and MODIS L2 optical depths
}

\section{S. DeSouza-Machado ${ }^{1}$, L. Strow ${ }^{1}$, E. Maddy ${ }^{2}$, O. Torres ${ }^{3}$, G. Thomas ${ }^{4,}{ }^{*}$, D. Grainger ${ }^{4}$, and A. Robinson ${ }^{5}$}

${ }^{1}$ Joint Center for Earth Systems Technology/Physics Department, University of Maryland, Baltimore County, Baltimore, MD, USA

${ }^{2}$ Riverside Technology, Inc, College Park, MD, USA

${ }^{3}$ NASA Goddard, Greenbelt, MD, USA

${ }^{4}$ Atmospheric, Oceanic and Planetary Physics, University of Oxford, Oxford, UK

${ }^{5}$ Radiation Oncology and Molecular Radiation Sciences, Johns Hopkins Hospital, Baltimore, MD, USA

"now at: Rutherford Appleton Laboratory Space, STFC Rutherford Appleton Laboratory, Harwell Science and Innovation Campus, Oxford, UK
Dust height using AIRS/MODIS synergy

S. DeSouza-Machado et al.

\section{Title Page}

\section{Abstract}

Introduction

Conclusions

References

Tables

Figures

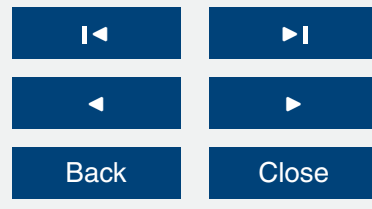

Full Screen / Esc

Printer-friendly Version

Interactive Discussion 
Received: 10 November 2014 - Accepted: 10 December 2014 - Published: 13 January 2015

Correspondence to: S. DeSouza-Machado (sergio@umbc.edu)

Published by Copernicus Publications on behalf of the European Geosciences Union.

AMTD

$8,443-485,2015$

Dust height using AIRS/MODIS synergy

S. DeSouza-Machado et al.

Title Page

Abstract Introduction

Conclusions References

Tables Figures

\begin{tabular}{c|c} 
I4 & $\Delta$ I \\
\hline Back & $\bullet$ \\
\hline & Close \\
\hline
\end{tabular}

Full Screen / Esc

Printer-friendly Version

Interactive Discussion 


\section{Abstract}

We present a novel method to retrieve daytime atmospheric dust and ash plume heights using a synergy of infrared hyper-spectral radiances and retrieved visible optical depths. The method is developed using data from the Atmospheric Infrared Sounder 5 (AIRS) and Moderate Resolution Imaging Spectroradiometer (MODIS), both of which are on NASA's Aqua platform, and lends itself to also a $\chi^{2}$ height derivation based on the smallest bias between observations and calculations in the thermal infrared window. The retrieval methodology is validated against almost 30 months of dust centroid heights obtained from the Cloud-Aerosol Lidar and Infrared Pathfinder Satellite Observations (CALIOP) data, and against ash plume heights obtained from the Advanced Along-Track Scanning Radiometer (AATSR) after the Puyehue Cordon Caulle volcanic eruption of June 2011. Comparisons are also made against Goddard Chemistry Aerosol Radiation and Transport (GOCART) climatological aerosol heights. In general there is good agreement between the heights from the CALIPSO data and the

15 AIRS/MODIS retrieval, especially over the Atlantic and Mediterranean regions; over land one there are more noticeable differences. The AIRS/MODIS derived heights are within typically $25 \%$ of the CALIOP centroid heights.

\section{Introduction}

The Earth's atmosphere consists of well mixed and stable gases such as nitrogen are constantly changing, and clouds and aerosols. While the gaseous atmosphere is mostly transparent to incoming solar radiation, the Outgoing Long wave Radiation (OLR) in the infrared is strongly absorbed and re-emitted by the trace and greenhouse gases.

25 In addition clouds and aerosols also significantly affect the incoming solar and outgoing thermal radiation. For example clouds and aerosols scatter and absorb both solar
AMTD

$8,443-485,2015$

Dust height using AIRS/MODIS synergy

S. DeSouza-Machado et al.

\section{Title Page}

Abstract Introduction

Conclusions References

Tables

Figures

14

4

Back

Printer-friendly Version

Interactive Discussion 
and thermal radiation. Radiative balance is affected by these atmospheric particles in ways that are not fully understood, and indeed the radiative effects of naturally occurring aerosols such as dust have not yet been determined accurately enough (IPCC, 2007) so as to be able to state whether the dominant aerosol radiative forcing effect is 5 one of cooling or heating. The dust scatters solar radiation and absorbs terrestrial radiation before eventually falling out of the atmosphere; the local heating changes air and surface temperatures and relative humidity in the vicinity of the dust, affecting tropical weather and hurricane formation; research studies of the effect of dust demonstrates the changes to atmospheric geophysical variables (Perez et al., 2006; Davidi et al., 10 2012), though the current AIRS L2 products do not account for the scattering effects of aerosols (Maddy et al., 2012). Aerosols indirectly affect climate by serving as nuclei for cloud formation, and as sites for chemical processes to occur (DeSouza-Machado et al., 2010).

Fine aerosol particles usually come from chemical processes and can cause res15 piratory problems. Larger aerosol particles, predominantly from atmospheric dust and volcanic events can limit visibility. Atmospheric dust is emitted by the action of wind blowing over arid regions; the dust emitted from the great deserts such as the Sahara and Gobi, is usually lofted into the troposphere and transported across continents (Koren et al., 2006) by the prevailing winds. Dust can affect the biochemistry of ocean coral reefs (DeSouza-Machado et al., 2006), and act as a nutrient source for phytoplankton. Springtime Asian "yellow" dust episodes cause health problems and blanket whole urban and farm areas, with associated cleaning costs and deposition of sand over good soil.

Eruptions from volcanoes impact human life both directly and indirectly. Indirect ef25 fects come from the ejected gases and rocks; the rock/ash plumes affect radiative forcing before they fall/precipitate out of the atmosphere in a few months. Sulfuric gases ejected high into the stratosphere become sulphate aerosols which can remain in the atmosphere for up to 2-3 years; these aerosols reflect incoming sunlight, which can cause stratospheric heating and tropospheric cooling. Chemical reactions involving

\section{AMTD}

$8,443-485,2015$

Dust height using AIRS/MODIS synergy

S. DeSouza-Machado et al.

\section{Title Page}

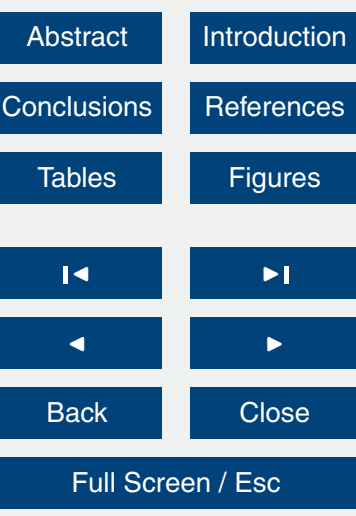

Printer-friendly Version

Interactive Discussion 
chlorofluorocarbons (CFCs) on the surface of the aerosols can destroy stratospheric ozone (Kirchner et al., 1999; Stenchikov et al., 1998). Though volcanic events are more isolated than dust storms, their direct impacts range from loss of life and destruction of property. Recent volcanic events have also led to financial impacts from the disrup5 tion and/or cancellation of large numbers of flights whose paths are expected to cross the ash plumes. Nine global Volcanic Ash Advisory Centers (VAAC), each having well defined geographic regions to monitor, are responsible for providing information about ash clouds and sulfur dioxide $\left(\mathrm{SO}_{2}\right)$ emissions that could pose hazards for the aviation industry, as winds can transport fine ash particles and $\mathrm{SO}_{2}$ many miles away from 10 the actual eruption; these fine particles can be missed by aircraft radar and clog or severely damage jet engines. The ash plumes cannot be visibly seen at night, while during the day the plume may resemble a water vapor or ice cloud. The VAACs use advection models to predict the distribution of ash and $\mathrm{SO}_{2}$, driven by Numerical Weather Prediction models. The accuracy is determined by the initial conditions, which are the 15 near-source injection heights of the ash.

For these and other reasons, detection and study of atmospheric clouds and aerosols is important. Instruments designed to observe radiative effects and retrieve aerosol and cloud properties operate mostly in the Near Infrared (NIR) to Visible (VIS) to Ultraviolet (UV) (3 to $0.2 \mu \mathrm{m})$, as this range of wavelengths is well suited to detect the scattering and absorptive effects both of small and large particles in the atmosphere. When mounted on satellites, these instruments cover huge swaths of the Earth's surface during daytime overpasses, and are mostly insensitive to the cloud and aerosol layer height. Conversely active instruments such as lidars and radars are very sensitive to the height and to some extent can differentiate between aerosol species; however the current generation of satellite-borne active instruments have very limited area coverage. Together, substantial progress has been made in the retrieval of macroscopic aerosol and cloud parameters such as optical depths and effective particle sizes (see for example the MODIS products described in Remer et al., 2005, and Platnick et al., 2003), and single scattering albedo and aerosol absorption optical depth from near-

\section{AMTD}

$8,443-485,2015$

Dust height using AIRS/MODIS synergy

S. DeSouza-Machado et al.

\section{Title Page}

Abstract Introduction

Conclusions References

Tables Figures

14

4

Back

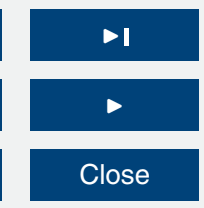

Full Screen / Esc

Printer-friendly Version

Interactive Discussion 
ultraviolet (near-UV) observations from the Ozone Monitoring Instrument (OMI) (Jethva et al., 2014; Ahn et al., 2014).

Though less sensitive than the above, passive infrared instruments that operate in the 15 to $4 \mu \mathrm{m}$ range work day and night, and "see" the radiative effects of larger par5 ticles such as water droplets and cirrus particles, as well as atmospheric dust and volcanic ash. Additionally most clouds affect the thermal infrared spectrum in the $\mathrm{CO}_{2}$ temperature sounding region which means other than sub-visible clouds, cloud heights can usually be determined via the $\mathrm{CO}_{2}$ slicing method (see for example Holz et al., 2006). However the infrared spectral signature of aerosols is quite different, and there 10 is still much to be done in operational retrieval of aerosol layer heights; more accurate determination of heights could for example lead to improved understanding of dustcloud interactions and modeling of dust sources and dust transport (Vandenbussche et al., 2013), as well as improve aerosol retrievals of UV instruments which have sensitivity to aerosol height (Torres et al., 2007).

15 When the appropriate refractive indices are used, Mie scattering theory shows that the retrieved optical depths in the infrared are about 2-4 times smaller than those retrieved in the visible (DeSouza-Machado et al., 2006, 2010). In order to retrieve an accurate optical depth using infrared radiances, dust/ash retrievals require both an estimate of the atmospheric temperature and humidity profiles, as well as accurate knowledge of the dust layer height. Previous work on obtaining height estimates of dust has ranged from a look-up table approach (Pierangelo et al., 2004), to assuming climatological heights (DeSouza-Machado et al., 2010) such as that from Goddard Chemistry Aerosol Radiation and Transport (GOCART) (Ginoux et al., 2001), to performing an iterative retrieval which minimized the observed - calculated bias radiances as a funccontaining about 1.5 pieces of information, or slightly more than knowledge about the peak of the profile (Vandenbussche et al., 2013).

In this paper, instead of obtaining optical depths using infrared radiances, we turn the primary focus for daytime observations into finding the mean aerosol height (i.e. 1

\section{AMTD}

$8,443-485,2015$

\section{Dust height using AIRS/MODIS synergy}

S. DeSouza-Machado et al.

\section{Title Page}

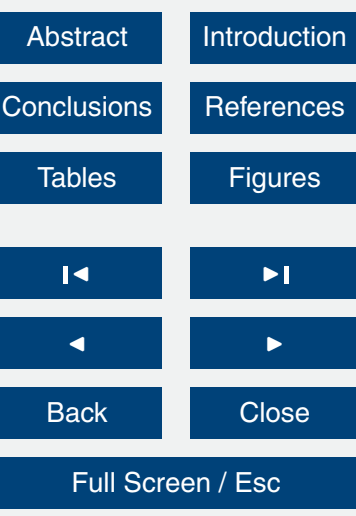

Printer-friendly Version

Interactive Discussion 
piece of information) by using the MODIS L2 retrieved optical depths as a constraint. This immediately allows us to have reliable estimates of dust- (and ash-) heights over large areas of the planet, rather than relying on climatology or sparser spatial measurements for instruments such as CALIPSO. Since our retrieval is based on loops to find 5 the height at which the IR: VIS optical depth ratio is $1: 4$, we are also able to simultaneously assess a height retrieval based on where the minimum $\chi^{2}$ between observations and calculations occur; this same looping can be used for a $\chi^{2}$ retrieval for night scenes, or when visible ODs are otherwise unavailable, such as over sun glint regions. We demonstrate the dust loading and height retrieval using co-located AIRS/MODIS 10 data. The estimates of plume heights and ash/cirrus loading are validated by comparison against other satellite-based instruments. Together, the results should prove valuable for operational use by VAACs for volcanic ash detection and comparison against models of ash dispersal and deposition, for dust source modeling and transport, and also for improving atmospheric retrievals in the presence of dust/ash.

The rest of the paper is organized as follows. We first describe the AIRS instrument, followed by a short discussion of the dust flag (DeSouza-Machado et al., 2010) used in the AIRS L1 and L2 products. This is followed by an outline of the retrieval algorithm, and a mention of the other instruments used in this paper. The algorithm is tested by retrieving 3 years of dust heights using AIRS data, with validation from a co-located lidar instrument. A second application to determine ash plume heights from a volcanic eruption in S. America is also described and validated.

\section{The AIRS instrument}

AIRS (Aumann et al., 2003) instrument on board NASA's polar orbiting Aqua satellite was designed to provide improved temperature and humidity profiles for numerical weather prediction and long-term climate studies. An overview of the AIRS instrument and clear sky radiative transfer algorithm (AIRS-RTA) on which the level 2 retrievals are based, are given in (Aumann et al., 2003; Strow et al., 2003). AIRS has 2378 in-
AMTD

$8,443-485,2015$

Dust height using AIRS/MODIS synergy

S. DeSouza-Machado et al.

Title Page

Abstract Introduction

Conclusions References

Tables Figures

14

4

Back

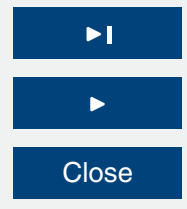

Full Screen / Esc

Printer-friendly Version

Interactive Discussion 
frared channels, broadly covering the $649-2665 \mathrm{~cm}^{-1}$ spectral range. The full widths at half maximum satisfy $v / \delta v \simeq 1200$, with the noise equivalent change in temperature $(N E \Delta T) \leq 0.2 \mathrm{~K}$. AlRS has a $13.5 \mathrm{~km}$ nadir footprint.

\subsection{Dust/ash detection}

5 Refractive indices of different atmospheric scattering species lead to distinct spectral signatures which impact measured InfraRed (IR) radiances in distinct ways. With (almost) complete high-spectral coverage of the 9-12 $\mu \mathrm{m}$ atmospheric window spectrum, data from AIRS (and other hyperspectral infrared sounders) have been demonstrated to contain much information when the particles are typically larger than $1 \mu \mathrm{m}$ in effective 10 radius. Examples include the retrieval of optical depths $\tau(v)$ of clouds (Kahn et al., 2003; Yue and Liou, 2009) and mineral based aerosols (dust, volcanic ash) (Carn et al., 2005; DeSouza-Machado et al., 2006, 2010; Gangale et al., 2009; Clarisse et al., 2010).

Silicate based absorbers such as desert dust and volcanic ash (basalt, andesite or obsidian) absorb less at the 800 and $1200 \mathrm{~cm}^{-1}$ regions than at $960 \mathrm{~cm}^{-1}$, and on 15 instruments on board high altitude aircraft or orbiting satellites cause a "V" shaped depression of the radiances (or equivalent Brightness Temperature (BT)) measured across the thermal IR window (Carn et al., 2005; DeSouza-Machado et al., 2006, 2010; Gangale et al., 2009; Vandenbussche et al., 2013; Kluser et al., 2011). This spectral feature allows infrared spectral data to be queried for dust or volcanic ash contamination day or night. Long term monitoring of the dust flag implemented in the AIRS L1 and L2 products shows that it performs very well over ocean for (visible) optical depths larger than about 0.15 , though depending on the dust source, the flag may not trigger during some episodes where the dust is coming off the northwest coast of Africa. Conversely surface emissivities serve to make the product have less skill over land.

25 The black curve in Fig. 1 shows an example of extreme infrared spectral measurement obtained by the AIRS instrument in the vicinity of the June 2011 Puyehue eruption over $\mathrm{S}$. America; notice the brightness temperature in the window region goes down to al-
AMTD

8, 443-485, 2015

Dust height using AIRS/MODIS synergy

S. DeSouza-Machado et al.

\section{Title Page}

Abstract Introduction

Conclusions References

Tables Figures

14

4

Back

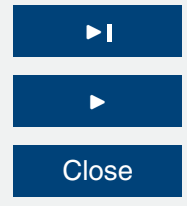

Full Screen / Esc

Printer-friendly Version

Interactive Discussion 
most $220 \mathrm{~K}$, which is the temperature of the tropopause, suggesting the ash is optically thick and at very high altitudes. The gray curve of Fig. 1 shows a more typical example of infrared spectral measurements obtained for dust or ash contaminated scenes; note this is also for high altitude ash, but the brightness temperature depression is 5 much less, which illustrates the complexity in separating out height from aerosol loading in infrared retrievals. Finally the light gray curve shows a typical measurement over clear ocean. Different aerosol absorbers would show similar V-shaped depressions but would have their own characteristic spectral signatures (see for example plots in DeSouza-Machado et al., 2006; Gangale et al., 2009).

10 Also designed for the same purposes, the Infrared Atmospheric Sounding Interferometer (IASI) on board the Metop-A polar orbiting satellite crosses the equator twice daily, with a 9:30 a.m. equatorial ascending node. Recently the CRiS (Cross track Interferometric Sounder) was launched on board the Suomi NPP satellite, in an orbit similar to that of Aqua AIRS; designed for same purposes as AIRS and IASI, all three instru15 ments have multiple channels in the thermal infrared window. With $\sim 2000 \mathrm{~km}$ swaths, the $\sim 90$ min Aqua, Metop-A and Suomi NPP orbits each yield almost twice daily coverage of every spot on Earth; in particular dust or volcanic ash in extreme latitudes can be more easily detected by an orbiting satellite than by a geostationary satellite looking mainly over one location. As infrared data can be acquired day or night, together these three infrared instruments potentially offer six daily views related to a dust or volcanic event, as long as there is no thick cloud overlying the aerosol.

\subsection{Retrieval algorithm for AIRS}

The MODIS constrained height retrieval algorithm is a straightforward adaption of the one used in DeSouza-Machado et al. (2010), the main parts of which are summarized 25 here. The Schwartzchild Equation (SE) models the radiative transfer through the atmosphere (Liou, 2002; Goody and Y. L., 1989). Dividing the atmosphere into the $~ 100$ layers used in the clear sky AIRS RTA (which are $0.25 \mathrm{~km}$ thick at the surface and about $0.35 \mathrm{~km}$ thick at $15 \mathrm{~km}$ ), we solve this equation by recasting the cloud/aerosol
AMTD

$8,443-485,2015$

Dust height using AIRS/MODIS synergy

S. DeSouza-Machado et al.

Title Page

Abstract Introduction

Conclusions References

Tables Figures

14

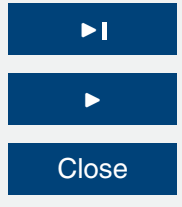

Full Screen / Esc

Printer-friendly Version
Interactive Discussion

\section{4} Back Interactive Discussion 
scattering parameters into an effective optical depth (Chou et al., 1999). The accuracy of the code is described in (DeSouza-Machado et al., 2010), where retrieved AIRS optical depths were compared against co-located aerosol optical depth retrievals from the other A-Train instruments operating in the visible and/or ultraviolet, for the case 5 of a February 2007 Mediterranean dust storm. The accuracy of the radiative transfer algorithm is sufficient to account for the effects of clouds and ash/dust on infrared radiances, and is dominated by errors when ascribing the height of the cloud/aerosol layer, as well as in refractive indices. The scattering algorithm has been integrated into the AIRS-RTA, henceforth called SARTA_scatter, such that the RTA retained its speed 10 and accuracy. A 2378 channel run takes $\leq 0.2 \mathrm{~s}$ on a $2.7 \mathrm{GHz}$ machine, and would be proportionally less for the handful of channels used for the retrieval.

The retrieval algorithm operates per AIRS granule, which is a 6 min span over which AIRS spectra are obtained, the instrument scanning $\pm 48^{\circ}$ on either side of nadir. The dust flag allows us to subset which of the spectra is dust contaminated, following which water vapor, ozone and temperature profiles and surface parameters needed to compute radiances are co-located using the nearest quarter degree grid point in the European Center for Medium Range Weather Forecasting (ECMWF) forecast or analysis model fields. Surface emissivity comes from (Masuda et al., 1988) over ocean, and from the MODIS-derived land database (Borbas et al., 2007). The aerosol (dust or ash) is assumed to uniformly fill the FOV and so we do not weight the radiance based on the clear vs. aerosol fractions. For dust, refractive indices come from the Saharan Dust optical parameters (collected in Barbados) compiled in Volz (1973) while for volcanic ash, basalt refractive indices are used (Pollack et al., 1973). The refractive constants of andesite and basalt are quite similar, so differences in size distributions would dominate the scattering parameters. Mie scattering parameters are computed using a uni-modal log normal particle size distribution $(\sigma=2 \mu \mathrm{m})$.

The retrievals use a small subset of the thermal infrared AIRS channels (DeSouzaMachado et al., 2010). For a fixed aerosol height and effective particle size, NewtonRaphson methods are used to retrieve aerosol loadings. The loadings $\Gamma_{j}$ in $\mathrm{g} \mathrm{m}^{-2}$ are

\section{AMTD}

8, 443-485, 2015

Dust height using AIRS/MODIS synergy

S. DeSouza-Machado et al.

\section{Title Page}

Abstract Introduction Conclusions References Tables Figures

14

4

Back

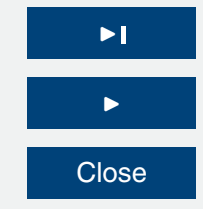

Full Screen / Esc

Printer-friendly Version

Interactive Discussion 
Here $\tau_{\text {dust/ash }}(v,\langle$ rme $\rangle)$ is the optical depth for an aerosol loading of $1 \mathrm{~g} \mathrm{~m}^{-2}$ and mean effective particle radius $\langle r m e\rangle$. A fixed maximum number of iterations (3) were used 5 in the retrievals for each height. The OD retrieval is performed for a set of discrete heights $z$ ranging from 1.5 to $6.0 \mathrm{~km}$ in steps of $0.5 \mathrm{~km}$ for dust, while for volcanic ash plumes the heights $z$ range from 2 to $15 \mathrm{~km}$ in steps of $1 \mathrm{~km}$. The retrieval has been parallelized for the latitude, longitude (lat, lon) pairs of the dust-contaminated pixels. As a rule of thumb, given a measured radiance spectrum having the characteristic "V" shaped depression, the height/loading combinations are such that if the aerosol is placed at a low altitude in the retrieval, the corresponding aerosol loading needed to optimize the fit is larger than if the aerosol were placed at a higher altitude; the highest sensitivity occurs lower in the atmosphere, where one tends to lose the surface contrast.

$15 \quad$ After running off the optical depth retrieval for each height step $z$, a $\chi^{2}$ ( $z$, lat, lon) value quantifying the difference in observations and calculations for a few channels in the thermal infrared window is computed for each aerosol contaminated (lat, lon) pixel; after all heights had been looped over, the optimal height $z_{\text {chi }}$ (lat, lon) at which the minimum $\chi^{2}(z)$ occurred is saved. At any retrieval height the accuracy of the $\chi^{2}$ ( $z$, lat, lon) values depend on the accuracy and appropriateness of the scattering parameters which were used; this also impacts the accuracy of the optimal height $z_{\text {chi }}$ (lat, lon).

Simultaneously for data obtained during the daytime, the dust contaminated AIRS observations were co-located to MODIS L2 optical depths (see below) and the height $z_{\text {MODIS }}$ (lat, lon) at which the MODIS/AIRS optical depth ratio was $f_{0}=4$ is also saved; 25 if the scene was night time the MODIS based height was assigned a NaN value. We point out that if the AIRS dust was located in a MODIS sun-glint region for which there is no retrieval, a $2 d$ (latitude/longitude) interpolation of the available MODIS L2 optical depth data was performed, so as to obtain a MODIS-based height estimate. Most dust

\section{Dust height using AIRS/MODIS synergy}

S. DeSouza-Machado et al.

\section{Title Page}

Abstract Introduction

Conclusions References

Tables Figures

14

4

Back

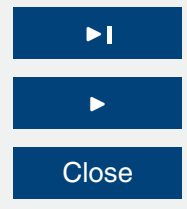

Full Screen / Esc

Printer-friendly Version

Interactive Discussion 
occurs in the topics or mid-latitudes, for which MODIS aerosol retrievals are available; an issue could arise for high latitude volcanic ash, as the MODIS aerosol algorithm is not used for large solar zenith angles. The accuracy of the daytime MODIS-derived heights would be mainly determined by the accuracy of the co-located MODIS L2 opti5 cal depths, and to a lesser extent the scattering parameters used in the AIRS retrieval scheme.

A set of monthly GOCART aerosol climatological heights (which does not distinguish between day or night) $z_{\text {GOCART }}$ (lat, lon, month) that has been made available to us, are also co-located and saved for each pixel. This means the retrieval package yields up 10 to three dust/ash heights.

\section{Height retrieval sensitivity}

The $961 \mathrm{~cm}^{-1}$ AIRS channel is typically most affected by silicate-based aerosols such as volcanic ash or desert dust, as it is spectrally close to the peak of the aerosol absorption, but still lies outside the $10 \mu \mathrm{m}$ ozone band which also affects TOA radi15 ances. Conversely the $1231 \mathrm{~cm}^{-1}$ channel is far less affected by aerosols. Together, this means the Brightness Temperature Difference (BTD) between these two channels (BT1231-BT961) is a very good indicator of dust presence, as exploited in the dust flag mentioned earlier. The BTD depends both on the aerosol loading and height - for a fixed dust column loading (in $\mathrm{g} \mathrm{m}^{-2}$ ), simulations using our scattering code show the 20 BTD varies almost linearly with height. For example for a dust loading of $1 \mathrm{~g} \mathrm{~m}^{-2}$ the BTD varies (almost linearly) from $0.2 \mathrm{~K}$ at $1.5 \mathrm{~km}$ height, to $4.9 \mathrm{~K}$ at $10 \mathrm{~km}$ height. We note here that when the height is increased to the tropopause, the sensitivity is lost the BTD remains the same for a given dust loading.

For any geophysical profile, this information can be turned into a height sensitivity as 25 follows. A dust loading of $1 \mathrm{~g} \mathrm{~m}^{-2}$ corresponds to a $10 \mu \mathrm{m}$ optical depth of 0.18 . Looping over both heights and over aerosol loadings (in $\mathrm{g} \mathrm{m}^{-2}$ ), we can build up a 2-D matrix $\mathcal{M}$ of how the BTD varies with the heights and AIRS optical depths. Using a factor $f_{0}$
AMTD

$8,443-485,2015$

Dust height using AIRS/MODIS synergy

S. DeSouza-Machado et al.

\section{Title Page}

Abstract Introduction

Conclusions References

Tables Figures

14

4

Back

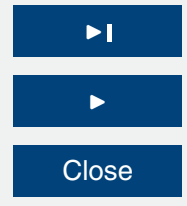

Full Screen / Esc

Printer-friendly Version

Interactive Discussion 
of 4 to change the AIRS optical depth to MODIS optical depth, means we now have a table of values for how the AIRS BTD changes with dust height and MODIS AOD (for $f_{0}=4$ ). We can use the same matrix $\mathcal{M}$ to change to another set of MODIS optical depths, but with a factor $f$, and use these to answer the question: for a fixed observed 5 AIRS BTD, and fixed retrieved MODIS L2 OD, how does the retrieved height $h$ change as the factor $f$ relating the infrared to visible optical depths is changed? Then

$\delta(\mathrm{BTD})=\frac{\partial(\mathrm{BTD})}{\partial h} \delta h+\frac{\partial(\mathrm{BTD})}{\partial \tau_{\mathrm{MODIS}}} \delta \tau_{\text {MODIS }}$

where the MODIS optical depth is related to the AIRS optical depth by $\tau_{\text {MODIS }}=f_{0} \tau_{\text {AIRS }}$, $f_{0}=4$, and the heights $h$ are in $\mathrm{km}$. Since the BTD is necessarily the same whatever 10 value of $f$ is used, $\delta$ (BTD) $=0$, while $\delta \tau_{\text {MODIS }}=\tau_{\text {AIRS }} \delta f$, where we ignore errors in the MODIS L2 product. This gives

$\delta h=-\frac{\left\{\frac{\partial(\mathrm{BTD})}{\partial \tau_{\mathrm{MODIS}}}\right\}}{\left\{\frac{\partial(\mathrm{BTD})}{\partial h}\right\}} \times \tau_{\mathrm{AIRS}} \delta f$

As mentioned above, we use $f_{0}=4$ and expect that value to vary between 3 and 5 , implying $\delta f= \pm 1$; the partial derivatives can easily be numerically evaluated, from which 15 we can obtain $\delta h$. Figure 2 illustrates the methodology. The left panel shows the (AIRS) BTD (values noted from the colorbar) as a function of height (in $\mathrm{km}$, horizontal axis, in steps of $0.125 \mathrm{~km}$ ) and MODIS AOD (vertical axis), where we used $f_{0}=4$ to convert the AIRS infrared optical depths to MODIS AOD. One sees that for low heights, the BTD does not change for smaller OD values; the changes are much smaller than when the dust is at higher altitudes.

The black and red crosshairs illustrate two points we chose - the black crosshairs corresponds to a hypothetical BTD of $+5 \mathrm{~K}$ while the MODIS AOD is 2 , and translates to a dust layer height of $4.125 \mathrm{~km}$, while the red crosshairs corresponds to a hypothetical BTD of $+5 \mathrm{~K}$ while the MODIS AOD is 1 , and translates to a dust layer height 455

\section{AMTD}

$8,443-485,2015$

Dust height using AIRS/MODIS synergy

S. DeSouza-Machado et al.

\section{Title Page}

Abstract Introduction

Conclusions References

Tables Figures

14

4

Back

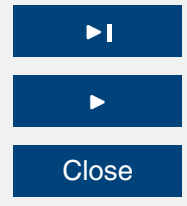

Full Screen / Esc

Printer-friendly Version

Interactive Discussion 
of $6.125 \mathrm{~km}$. Not shown here is how these crosshairs move when we use a value of $f=3$ or $f=5$; the former makes the black/red crosshairs move to $3.625 \mathrm{~km} / 4.625 \mathrm{~km}$ while the latter makes the black/red crosshairs move to $4.625 \mathrm{~km} / 7.500 \mathrm{~km}$. This gives a sensitivity of about 0.6 and $1.3 \mathrm{~km}$ for the black and red cross hairs respectively. The 5 right hand panel shows the computed uncertainty using the expressions given above for a uncertainty $\delta f=+1$, and one sees from the shading at the crosshairs that we get good agreement with the expected numbers.

As the climatology is changed (from example from tropical to US Standard to Mid Latitude Summer), one notices variations in the $2 d$-sensitivity plot, but the overall fea10 tures remain the same; namely the larger sensitivity at low optical depths/high altitudes, compared to larger optical depths/lower altitudes. This same methodology can be applied to the NWP fields associated with any pixel. However on a granule basis, it is easier to average the NWP profiles and do just one sensitivity study whose results can be applied to all dust/ash contaminated pixels present, at most separating out land 15 from ocean scenes.

Figure 2 illustrates the multi-valued nature of the BTDs - for example the crosshairs are for the same BTD of $5 \mathrm{~K}$, but occur at different (optical depth, height) pairs; one sees almost any BTD combination can be found at multiple pairings. Plots with the same qualitative features can be made for other pairs of thermal infrared channels, which 20 would slightly change the locations of the (optical depth, height) pairs. This makes a $\chi^{2}$ retrieval feasible. However the values of $\chi^{2}=\sum_{i}(\mathrm{obs}(i)-\mathrm{cal}(i))^{2}$ would be affected by errors in the calculations for example due to incorrect size distributions and scattering parameters. This makes the $\chi^{2}$ less robust than the AIRS/MODIS synergy, and also harder to assign uncertainties to. Height sensitivity for the $\chi^{2}$ retrieval was assessed of the curve was typically observed, spanning about $\pm 1.5 \mathrm{~km}$.

\section{AMTD}

$8,443-485,2015$

Dust height using AIRS/MODIS synergy

S. DeSouza-Machado et al.

\section{Title Page}

Abstract Introduction

Conclusions References

Tables Figures

14

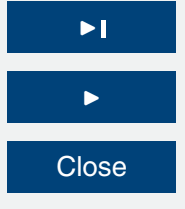

Full Screen / Esc

Printer-friendly Version

Interactive Discussion 


\section{Other instruments used in this study}

Data products from three instruments are also used in this paper. The visible optical depths used to constrain the daytime infrared retrievals come from NASA's MODIS instrument, which is on the same Aqua platform as the AIRS instrument. The Aqua 5 satellite is part of the A-train constellation, which consists of six satellites in sunsynchronous orbits at an altitude of approximately $700 \mathrm{~km}$ above the Earth at an inclination of $98.14^{\circ}$. The afternoon (A)-train satellites cross the equator at roughly 1:30 p.m. (local time) in an ascending (daylight) mode. The orbit times are $90 \mathrm{~min}$ with a repeat cycle of 16 days. Dust height validation comes from using data products from Cloud-

10 Aerosol Lidar with Orthogonal Polarization (CALIOP), a lidar based instrument on the CALIPSO satellite which is also part of the A-train satellite constellation; this means the CALIPSO platform is on the same orbit as the Aqua platform, though it lags behind by about a minute.

Ash plume height comparisons come from the Advanced Along-Track Scanning Ra15 diometer (AATSR) on board the the European Space Agency (ESA) ENVISAT satellite. This satellite was launched on 1 March 2002 into a sun-synchronous polar orbit at an altitude of $800 \mathrm{~km}$, at an inclination of $98.55^{\circ}$, crossing the Equator at 10:00 a.m. local time in a descending mode. It orbits the Earth in about 101 min with a repeat cycle of 35 days. The ENVISAT mission was ended in May 2012 after contact was lost with the satellite.

\subsection{MODIS}

MODIS is a high spatial resolution instrument $(\leq 1 \mathrm{~km})$ that acquires data in 36 spectral bands ranging from the visible to the TIR. The MODIS Level 2 aerosol products assume spherical particles to retrieve primary products, from which a number of other parameters are derived and reported such as mean particle size, fine/coarse mode ratio and Angstrom coefficients (Remer et al., 2005). All six visible and near infrared channels are used to find the best fit between a combination of models in

\section{AMTD}

$8,443-485,2015$

Dust height using AIRS/MODIS synergy

S. DeSouza-Machado et al.

\section{Title Page}

Abstract Introduction

Conclusions References

Tables Figures

14

4

Back

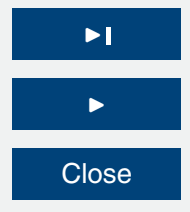

Full Screen / Esc

Printer-friendly Version

Interactive Discussion 
a look up table and the measured radiances. Once the aerosol model is derived, the optical depth is retrieved from the $865 \mathrm{~nm}$ channel since it has the smallest uncertainties from background particles and water-leaving radiances. For this work, we use the Optical_Depth_Land_And_Ocean product, which is the Aerosol Optical Thick5 ness at $0.55 \mu \mathrm{m}$ for both Ocean (best) and Land (corrected) with best quality data (QA Confidence Flag =3), which is a combination of the over ocean is the Effective_Optical_Depth_Average_Ocean total (fine+coarse) OD product and the MODIS Deep Blue retrieval algorithm (Hsu et al., 2004). Comparisons between the Deep Blue algorithm and AERONET (Holben et al., 1998) sun photometers show agreement to 10 within $20 \%$ for dust retrievals over (bright) land surfaces (Hsu et al., 2004). The $10 \mathrm{~km}$ aerosol product was co-located against pixels identified as dust/ash by the AIRS dust flag as needed. In this paper we use the MODIS L2 Collection 051 data.

\subsection{CALIOP}

The CALIOP lidar on CALIPSO (Winker et al., 2004) provides optical properties and 15 altitude resolution of clouds and aerosols, including dust. CALIOP was launched in late April 2006 and became operational in June 2006. It is a two-wavelength lidar that transmits and receives back-scattered light at laser wavelengths of 532 and $1064 \mathrm{~nm}$. CALIOP also has a polarization channel for the $532 \mathrm{~nm}$ wavelength. The CALIOP laser has a $25.25 \mathrm{~Hz}$ repetition rate with a $70 \mathrm{~m}$ surface footprint. The data have $30 \mathrm{~m}$ vertical 20 resolution from the surface to $8 \mathrm{~km}$ altitude, and $60 \mathrm{~m}$ resolution above, with minimum horizontal resolution of a single profile of $1 / 3 \mathrm{~km}$. A typical horizontal averaging interval is $5 \mathrm{~km}$ ( 15 profiles) for aerosols and dust. CALIOP is a nadir-only instrument, covering far less of the globe than AIRS or MODIS. CALIPSO follows a similar ground track to Aqua, offset by $170 \mathrm{~km}$ from AIRS nadir, and lagging by about a minute. The L2 prod25 ucts include cloud and aerosol detection information on a $5 \mathrm{~km}$ horizontal grid; the information is broken into aerosol subtype (for example dust, smoke, marine aerosols) and the optical properties are divided into for example extinction and optical depth (Winker et al., 2009). For this paper the L2 weighted mean aerosol heights were daily co-located

\section{AMTD}

$8,443-485,2015$

Dust height using AIRS/MODIS synergy

S. DeSouza-Machado et al.

Title Page

Abstract Introduction

Conclusions References

Tables Figures

14

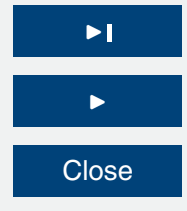

Printer-friendly Version
Full Screen / Esc

Interactive Discussion

\section{4} Back ing 
against MODIS L2 data; we note these heights were then averaged over a month for use as a climatological database with the OMI aerosol retrieval algorithm (Torres et al., 2013). No differentiation was needed to be made between different aerosol subtypes seen by CALIOP as the AIRS dust flag allows us to select the co-located dust/ash 5 heights.

\subsection{AATSR}

AATSR was a multi-channel imaging radiometer which provides two views of the Earth's surface, one centered at nadir and the other at $55^{\circ}$ from zenith, providing collocated views with atmospheric path lengths differing by a factor of two. The instrument provided measurements of reflected and emitted radiation in seven channels centered at $0.55,0.66,0.87,1.6,3.7,11$ and $12 \mu \mathrm{m}$, with a $1 \mathrm{~km}$ nadir resolution and a $512 \mathrm{~km}$ swath. AATSR was aboard ESA's ENVISAT platform, which was operation from mid2002 until April 2012 and provided a 10:30 a.m. local solar time sun-synchronous orbit.

AATSR was the third in a series of Along-Track radiometers designed to provide high precision and accuracy measurements of sea surface temperature, however they have been applied to the retrieval of a wide range of atmospheric and surface parameters including cloud and aerosol properties (Sayer et al., 2011; de Leeuw et al., 2013), as well as land surface temperature and classification. In particular, the parallax between the two views allows the retrieval of so called stereo cloud top height, through purely ple). (Grainger et al., 2013) present a Stereo Ash Plume Height retrieval algorithm that uses the distinctive ash (and mineral dust) signature between the 11 and $12 \mu \mathrm{m}$ channels (corresponding to 910 and $833 \mathrm{~cm}^{-1}$ in Fig. 1) to provide high contrast images of volcanic ash plumes, aiding in the stereo imaging matching. This algorithm, amongst other data, was tested on the Puyehue-Cordón Caulle eruption of June 2011.

The AATSR instrument provides height retrievals over the peak Puyehue-Cordón Caulle eruption period; CALIOP data was mostly unavailable during this time since the
AMTD

$8,443-485,2015$

Dust height using AIRS/MODIS synergy

S. DeSouza-Machado et al.

\section{Title Page}

Abstract Introduction

Conclusions References

Tables Figures

14

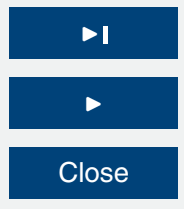

Full Screen / Esc

Printer-friendly Version

Interactive Discussion 
instrument had been turned off due to a solar flare event (http://www-calipso.larc.nasa. gov/tools/instrument_status/).

\section{Results and discussions}

In this section we show the results of the MODIS-constrained and $\chi^{2}$-daytime AIRS 5 height retrievals, and compare them to available data as well as to GOCART climatology. The first example spans about 3 years of dust height retrievals, for which we co-located mean aerosol layer heights from CALIOP data for about half that time. The second example is retrieval of ash plume heights from the June 2011 Puyehue eruption in S. America; CALIOP data is unavailable for this time, and so we use AATSR height retrievals for validation.

\subsection{Dust heights from January 2006 to December 2009}

Here we show a summary of height retrievals between January 2006 and December 2009; for 30 months within this time period (July 2006-December 2008) we colocated CALIOP mean aerosol heights against MODIS L2 daytime (ascending A-Train 15 mode) data (Torres et al., 2013). We separate out the results into four regions: Atlantic, Mediterranean, Pacific, and Africa/Arabia. The first three are mostly over water while the last is mostly over land masses. For all the figures in this section, blue circles (and shaded error bars) correspond to the mean (and standard deviation) of the monthly GOCART climatology; similarly red crosses correspond to the AIRS/MODIS height retrievals, green squares to the $\chi^{2}$-based AIRS retrievals, while black diamonds correspond to the mean CALIOP aerosol heights.

For each region, plots with two panels are presented. The left hand panel shows the seasonal cycle over the 2006-2009 period, together with the month to month variation of heights during the seasons. The right hand panel shows the mean over the 36 months and the corresponding variation of the mean from year to year, which is

\section{Dust height using AIRS/MODIS synergy \\ S. DeSouza-Machado et al.}

\section{Title Page}

Abstract Introduction

Conclusions References

Tables Figures

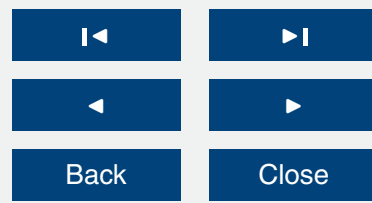

Full Screen / Esc

Printer-friendly Version

Interactive Discussion 
less than the individual monthly variation. We also note that the GOCART climatology varies both temporally and spatially, and so depending where the dust storms were found year to year, there could be variations in the averaged GOCART climatological heights.

$5 \quad$ Figure 3 shows the temporal height variation over the Atlantic region. Clearly seen in the left panel is the seasonal cycle, with the aerosol layers at about $2 \mathrm{~km}$ in the late fall/winter, and rising to about $4 \mathrm{~km}$ in the summer. For the years considered here, the climatology shows a slight phase shift, typically lagging behind the data by about a month or two, but on average is in general agreement with the data. The right panel 10 shows that in general the AIRS MODIS and $\chi^{2}$ retrievals agree with each other over the Atlantic and in general agree with the CALIOP heights; however the GOCART climatology places the dust lower in the spring and summer months, a manifestation of the phase shift evident in the time series, and as seen in Table 1 serves to lower the correlation with the CALIOP data.

The left panel of Fig. 4 shows the temporal height variation over the Pacific region, and shows it is mostly limited to the expected Springtime Asian dust. Also seen is the GOCART climatology (blue curve) typically being between 4-6 km, while both the CALIOP and AIRS heights suggest lower dust altitudes $(2 \mathrm{~km})$ in late winter, rising to about $4 \mathrm{~km}$ by late Spring. Averaged over the 3 year time period, the right panel clearly shows the GOCART climatology places the dust too high at all months. In addition in the early Spring the AIRS derived heights are slightly higher than those from CALIOP, and almost $1 \mathrm{~km}$ higher in the summer. One also sees a negative trend in the AIRS derived heights over the 4 year interval.

Figure 5 shows the temporal height variation over the Mediterranean region. Espe25 cially in the summer, the CALIOP data is generally slightly higher than that retrieved from the AIRS data, while the GOCART climatology falls in between the CALIOP and AIRS heights, being higher in the early Spring and lower in the summer, but overall agreeing with the CALIOP and AIRS derived heights.
AMTD

8, 443-485, 2015

Dust height using AIRS/MODIS synergy

S. DeSouza-Machado et al.

Title Page

Abstract Introduction

Conclusions References

Tables Figures

14

4

Back

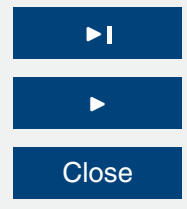

Full Screen / Esc

Printer-friendly Version

Interactive Discussion 
Finally Fig. 6 shows the temporal height variation over the African and Asian regions, typically the Sahara and Middle Eastern deserts. The GOCART climatology in general shows the lowest heights, while there are large differences in the MODIS/AIRS vs. $\chi^{2}$ based retrievals, which we attribute both to land emissivity issues and potential 5 inaccuracies with MODIS Deep Blue algorithm over land; for a few months the average $\chi^{2}$ retrieval is closer to the CALIOP data than the AIRS/MODIS retrieval. This is more clearly seen in the right panel of the figure, which shows that of all the four regions considered, the largest differences between the heights are over the African/Asian land masses, where typically the $\chi^{2}$-based AIRS height was the highest, especially in the 10 late summer months, while the CALIOP heights lay in between these and the GOCART climatology. Figure 3e of Shi et al. (2013) suggests the MODIS Deep Blue algorithm slightly overestimates lower optical depths, and underestimates optical depths greater than about 2; the former case of OD overestimation would lead to the AIRS/MODIS height algorithm placing dust layers lower in the atmosphere.

In summary, the GOCART aerosol climatological heights compared well against the MODIS based heights and the $\chi^{2}$ based heights, except noticeably for the springtime Asian dust over the Pacific, when the GOCART heights were much higher than the other two heights, and to a lesser extent over the Africa/Middle East land masses. All four heights showed similar seasonal height variations. The correlations between the CALIOP heights and the rest of the heights for the monthly averaged data are shown in Table 1.

In particular the $\chi^{2}$-based retrieval produced similar results to the MODIS-based height retrieval, which is promising for applying the algorithm for nighttime scenes. This is summarized in the left portion of Table 2, where one also sees that over land the $\chi^{2}$-based retrieval differed the most from the other heights. Though not shown here, plots similar to the right hand panels of Figs. 3 to 6 , but for the variability of the monthly heights, yields the statistics shown in the right portion of Table 2, indicating that the variability in the $\chi^{2}$ retrieval can almost be double that of the other data (MODISbased, CALIOP and GOCART), while that of the GOCART climatology is least.
AMTD

$8,443-485,2015$

Dust height using AIRS/MODIS synergy

S. DeSouza-Machado et al.

Title Page

Abstract Introduction

Conclusions References

Tables Figures

14

4

Back

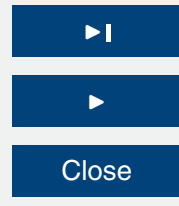

Full Screen / Esc

Printer-friendly Version

Interactive Discussion 


\subsection{Ash plume heights for the Puyehue-Calderon June 2011 eruption}

Chile's Puyehue-Cordon Caulle Volcanic Complex $\left(40.5^{\circ} \mathrm{S}, 72.1^{\circ} \mathrm{W}\right)$ belongs to the Lago Ranco chain, which is composed of basalt and rhyolite. An eruption commencing 3 June 2011, was violent enough for plumes to be ejected $11 \mathrm{~km}$ or more into the 5 atmosphere; less than $24 \mathrm{~h}$ later ash fall was being reported in Argentina, east of the volcano. An initial CALIOP browse image obtained at the beginning of the eruption on 5 June 2011 showed the ash and cloud height at about $12 \mathrm{~km}$. The CALIOP instrument was then turned off for about 10 days following a solar event. However, during these same days the AIRS dust flag showed the ash circumvented the Southern Hemisphere in the extra-tropics; by 11 June 2011 the volcanic ash plume had circumnavigated the entire Southern Hemisphere (south of $-40^{\circ} \mathrm{S}$ ) and was approaching the western coast of the S. American continent. In other words, the eruption loaded the Southern Hemisphere atmosphere with volcanic ash as well as clouds for a number of days (Grainger et al., 2013) at altitudes high enough to impact aviation in the region.

Unlike the previous subsection where the AIRS/MODIS height retrieval was temporally and spatially coincident with the CALIOP heights, here the AIRS/MODIS data from the Aqua satellite is unlikely to be temporally coincident with the AATSR height data. In order to validate the data, for each day that we had height retrievals, we compared probability distribution functions (pdfs) of the AATSR vs. AIRS/MODIS heights, where the daily pdfs were constructed using data limited to AIRS/MODIS being located within $10^{\circ}$ of the central location of the AATSR data. The timing of the eruption, during the Southern Hemisphere winter coupled with the ash potentially being transported to high latitudes, also meant that the sun could be quite low in the horizon for many of the AIRS/MODIS Aqua overpasses. Collection 051 does not have retrievals for solar angles larger than $72^{\circ}$ (this has been expanded to $84^{\circ}$ for Collection 6 retrievals; Levy et al., 2013); for the June 2011 eruption, this limitation can be triggered at latitudes higher than $47^{\circ} \mathrm{S}$.

\section{AMTD}

$8,443-485,2015$

Dust height using AIRS/MODIS synergy

S. DeSouza-Machado et al.

\section{Title Page}

Abstract Introduction

Conclusions References

Tables Figures

14

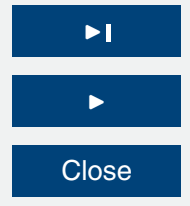

Back Close

Full Screen / Esc

Printer-friendly Version

Interactive Discussion 
Figures 7 and 8 show the AATSR and AIRS height retrievals for 6 June 2011. The AATSR data we have is limited to the $S$. American continent, while the AIRS data shows the plume has already blown over the S. Atlantic. Figure 9 shows the corresponding pdf comparisons; the thick curves show the "co-located" pdfs, which for 6 June 2011 would 5 be mostly limited to be within the continent of S. America, while the thinner dashed curves are for all the AIRS retrieved heights. One sees that both AIRS and AATSR see a dichotomous height distribution. The low altitude heights for AATSR are mostly in the $5 \mathrm{~km}$ range, while both the $\chi^{2}$ and MODIS based AIRS height retrievals are more broadly distributed around $5-8 \mathrm{~km}$, The high altitude AIRS heights are themselves 10 double peaked, with one peak at $13 \mathrm{~km}$ and the other at $15 \mathrm{~km}$, and is likely due to the retrieval losing its sensitivity at higher altitudes.

Instead of showing data for all the remaining days, we summarize the findings by stating that overall the time differences between the two data sets prevent detailed comparisons, but the above results are duplicated for the days from 7-14 June 2011.

By 11 June 2011, Fig. 10 for the AIRS/MODIS combination showed some of the ash was at a height of almost $18 \mathrm{~km}$ near Australia; in fact some ash at a height of $15 \mathrm{~km}$ had circumvented the Southern Hemisphere and come back to the S. American continent, as shown by the high altitude co-located AATSR/AIRS pdf peaks in Fig. 11. Also evident from the spatial distributions of detected ash in Figs. 8 and 10 is that, as with dust, the infrared ash detection is dependent on no clouds overlying/obscuring the aerosol.

A height sensitivity analysis using heights up to $20 \mathrm{~km}$ and a tropical profile, similar to that in Fig. 2, showed that at the height uncertainties (using a default factor of 4 when converting AIRS $\rightarrow$ MODIS optical depths), can translate to height uncertainties as large as $3-4 \mathrm{~km}$, especially for low optical depths.

Finally Fig. 12 shows results from a NOAA Hybrid Single-Particle Lagrangian Integrated Trajectory (HYSPLIT) Model trajectory run (Draxler and Hess, 1998; Draxler and Rolph, 2014), initialized at different heights on 5 June 2011 and run to 11 June 2011. The model is used for computing simple air parcel trajectories to complex dispersion and deposition simulations, and the runs show the air masses initialized between 12-

\section{AMTD}

$8,443-485,2015$

Dust height using AIRS/MODIS synergy

S. DeSouza-Machado et al.

\section{Title Page}

Abstract Introduction Conclusions References Tables Figures

14

4

Back

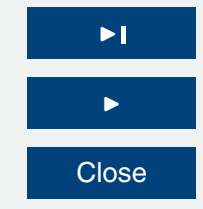

Full Screen / Esc

Printer-friendly Version

Interactive Discussion 
$13 \mathrm{~km}$ on 5 June 2011 remained relatively stable and traversed the Southern Hemisphere within a week.

\section{Conclusions}

We have demonstrated a daytime large aerosol particle (atmospheric dust/volcanic ash) height retrieval which uses visible sensor optical depths as a constraint to retrieve the heights from infrared radiances. Infrared radiances are sensitive both to aerosol loading and aerosol layer heights; since the visible to optical depth ratio is nominally on the order of 4 when the aerosol heights are correct, an iterative retrieval is used where the aerosol height is varied until this ratio is obtained. The obvious limit to this methodology is the availability of the visible optical depths, which for the MODIS is sensor is limited to daytime, over areas not contaminated by sun-glint. In addition the method relies on the accuracy of the visible ODs, which is better over ocean than over land. Other limitations include the refractive indices and particle size distributions (and effective sizes) used in the infrared retrieval. An analytic expression relating AIRS/MODIS 15 synergy height retrieval uncertainties to observed BTDs and MODIS L2 optical depths was derived, which can be applied to any geophysical profile.

The technique has been used to retrieve dust layer heights for the 2006-2009 period, and validated for the 30 months for which we co-located dust heights obtained from the CALIOP instrument. In general we see good agreement between the CALIOP and AIRS/MODIS heights; over the Pacific we note that the GOCART climatology for springtime aerosols yields heights that are significantly higher than those obtained from either retrieval scheme described above, while the largest differences between AIRS and CALIOP heights are over the Africa/Asia land masses. Since the technique is limited to daytime scenes, while looping over aerosol heights in the retrieval we also save off the height where the thermal infrared window spectral difference between AIRS observations and calculations are minimized; the results over the Atlantic in particular show good agreement with the other methods, but emissivity issues degrade the per-
AMTD

$8,443-485,2015$

Dust height using AIRS/MODIS synergy

S. DeSouza-Machado et al.

\section{Title Page}

Abstract Introduction

Conclusions References

Tables Figures

14

4

Back

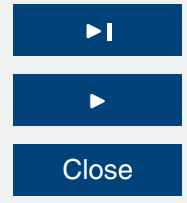

Full Screen / Esc

Printer-friendly Version

Interactive Discussion 
formance over land. In addition we also retrieved volcanic ash heights for the June 2011 Puyehue eruption in S. America; the validation data came from the AATSR instrument as there was no CALIOP data available.

The work in this paper assumes that the visible/infrared optical depth ratio $f_{0}$ is 4 . 5 The heights from CALIOP are usually higher than that retrieved from the AIRS/MODIS synergy; the height sensitivity of Sect. 3 shows that typically if $f$ increases, the retrieved height decreases; this means that the MODIS/AIRS ratio is probably less than 4 , though differences in size distributions and refractive indices used to compute the MODIS vs. AIRS scattering parameters, make this conjecture difficult to investigate fur10 ther. In addition depending on the magnitude of the optical depth involved, the infrared measurements can penetrate some way into the dust/ash plume and could result in a retrieved heights lower than the CALIOP centroid height.

With infrared missions being planned into the foreseeable future, data assimilation from instruments such as AIRS/MODIS, IASI/AVHRR and CRiS/VIIRS can be used

to improve source, transport and deposition models both for atmospheric dust and VAACs, in conjunction with data from other satellite instruments. Previous papers have demonstrated that databases of infrared spectral signatures (Gangale et al., 2009) can further be used to identify spieciation of dust and ash; in this paper the optimal results for AIRS data were obtained using optical constants of Saharan dust and basalt.

In the future we plan to utilize this height and optical depth retrieval in an Optimal Estimation scheme (Rodgers, 2000) as a constraint on a scattering-based retrieval of atmospheric humidity and temperature fields in the presence of aerosols, which should improve the AIRS L2 products when aerosols are present, as indicated by the dust flag. Bright surfaces negatively impact aerosol optical depth retrievals of instruments operating in the visible wavelengths over deserts; the aerosol ODs are more accurately retrieved using shorter wavelengths but which also need height estimates of the aerosols, which implies improved height retrievals could be used to improve for example aerosol ODs retrieved using instruments operating in the ultraviolet regimes.

\section{AMTD}

$8,443-485,2015$

Dust height using AIRS/MODIS synergy

S. DeSouza-Machado et al.

\section{Title Page}

Abstract Introduction

Conclusions References

Tables Figures

14

4

Back

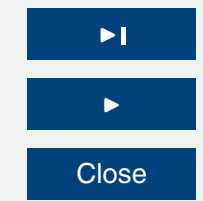

Full Screen / Esc

Printer-friendly Version

Interactive Discussion 
Acknowledgements. This work has been supported by a NASA-JPL contract NNN12AA01C with Science and Technology Corporation (STC), Columbia MD. We acknowledge the use of ECMWF model fields to compute radiances. Ruben Delgado ran off the NOAA HYSPLIT model. Paul Schou provided assistance in downloading the relevant AIRS L1B data co-located with 5 the dust flag using OpenDap, and with plotting the data. The development of the AATSR stereo height retrieval was supported by the UK Natural Environment Research Council (NERC) National Centre for Earth Observation and the NERC VANAHEIM project (NE/1015592/1). The hardware used in the computational studies is part of the UMBC High Performance Computing Facility (HPCF). The facility is supported by the US National Science Foundation through the

10 MRI program (grant nos. CNS-0821258 and CNS-1228778) and the SCREMS program (grant no. DMS-0821311), with additional substantial support from the University of Maryland, Baltimore County (UMBC). See www.umbc.edu/hpcf for more information on HPCF and the projects using its resources.

\section{References}

15 Ahn, C., Torres, O., and Jethva, H.: Assessment of OMI near-UV aerosol optical depth over land, J. Geophys. Res., 119, 2547-2473, doi:10.1002/2013JD020188, 2014. 448

Aumann, H., Chahine, M., Gautier, C., Goldberg, M., Kalnay, E., McMillin, L., Revercomb, H., Rosenkranz, P., Smith, W., Staelin, D., Strow, L., and Susskind, J.: AIRS/AMSU/HSB on the Aqua Mission: Design, Science Objectives, Data Products and Processing Systems, IEEE T. Geosci. Remote, 41, 253-264, 2003. 449

Borbas, E., Moy, L., Seeman, S., Knuteson, R., Trigo, I., Antonelli, P., Li, J., and Huang, H. L.: A global infrared land emissivity database and its validation, in: 11th Symposium on Integrated Observing and Assimilation Systems for Atmosphere, Oceans and Land Surfaces, San Antonio, TX, Paper P2.7, Call number 5285, 2007. 452

25 Carn, S., Strow, L., DeSouza-Machado, S., Edmonds, Y., and Hannon, S.: Quantifying tropospheric volcanic eruptions with AIRS: the 2002 eruption of Mt. Etna (Italy), Geophys. Res. Lett., 32, L02301, doi:10.1029/2004GL021034, 2005. 450

Chou, M.-D., Lee, K.-T., Tsay, S.-C., and Fu, Q.: Parameterization for cloud longwave scattering for use in atmospheric models, J. Climate, 12, 159-169, 1999. 452
AMTD

8, 443-485, 2015

\section{Dust height using AIRS/MODIS synergy}

S. DeSouza-Machado et al.

\section{Title Page}

Abstract Introduction

Conclusions References

Tables Figures

14

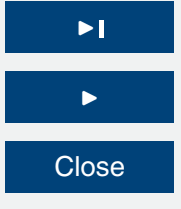

\section{Full Screen / Esc}

Printer-friendly Version

Interactive Discussion 
Clarisse, L., Hurtmans, D., Prata, A. J., Karagulian, F., Clerbaux, C., De Mazire, M., and Coheur, P.-F.: Retrieving radius, concentration, optical depth, and mass of different types of aerosols from high-resolution infrared nadir spectra, Appl. Optics, 49, 3712-3722, doi:10.1364/AO.49.003713, 2010. 450

5 Davidi, A., Kostinski, A., Koren, I., and Lehahn, Y.: Observational bounds on atmospheric heating by aerosol absorption: Radiative signature of transatlantic dust, Geophys. Rev. Lett., 39, L04803, doi:10.1029/2011GL050358, 2012. 446

de Leeuw, G., Holzer-Popp, T., Bevan, S., Davies, W., Descloitres, J., Grainger, R., Griesfeller, J., Hecket, A., Kinne, S., Kluer, L., Kolmonen, P., Litvinov, P., Martynenko, D., North, P., Ovigneur, B., Pascal, N., Poulsen, C., Ramon, D., Schulz, M., Siddans, R., Sogacheva, L., Tanre, D., Thomas, G., Virtanen, T., von Hoyningen Huene, W., Vountas, M., and Pinnock, S.: Evaluation of seven European aerosol optical depth retrieval algorithms for climate analysis, Remote Sens. Environ., online first, doi:10.1016/j.rse.2013.04.023, 2013. 459

DeSouza-Machado, S., Strow, L. L., Motteler, H., and Hannon, S.: Infrared dust spectral signatures from AIRS, Geophys. Res. Lett., 33, L03801, doi:10.1029/2005GL024364, 2006. 446, $448,450,451$

DeSouza-Machado, S., Strow, L. L., Imbiriba, B., McCann, K., Hoff, R., Hannon, S., Martins, J., Tanré, D., Deuzé, J., Ducos, F., and Torres, O.: Infrared retrievals of dust using AIRS: comparisons of optical depths and heights derived for a North African dust storm to other collocated EOS A-Train and surface observations, J. Geophys. Res., 115, D15201, doi:10.1029/2009JD012842, 2010. 446, 448, 449, 450, 451, 452

Draxler, R. and Hess, G.: An overview of the HYSPLIT_4 modeling system of trajectories, dispersion, and deposition, Aust. Meteorol. Mag., 47, 295-308, 1998. 464

Draxler, R. and Rolph, G.: HYSPLIT (HYbrid Single-Particle Lagrangian Integrated Trajectory) model access via NOAA ARL READY website, Tech. rep., NOAA Air Resources Laboratory, Silver Spring, MD, available at: http://ready.arl.noaa.gov/HYSPLIT.php (last access: 12 January 2015), 2014. 464

Fisher, D., Muller, J.-P., and Yershov, V.: Automated stereo retrieval of smoke plume injection heights and retrieval of smoke plume masks from AATSR and their assessment with CALIPSO and MISR, IEEE T. Geosci. Remote, 52, 1249-1258, doi:10.1109/TGRS.2013.2249073, 2014. 459

Gangale, G., Prata, A., and Clarisse, L.: On the infrared spectral signature of volcanic ash, Remote Sens. Environ., 114, 414-425, doi:10.1016/j.rse.2009.09.007, 2009. 450, 451, 466

\section{AMTD}

8, 443-485, 2015

\section{Dust height using AIRS/MODIS synergy}

S. DeSouza-Machado et al.

\section{Title Page}

Abstract Introduction

Conclusions References

Tables Figures

14

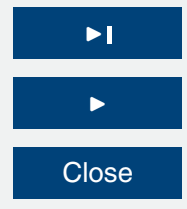

Back

Close

Full Screen / Esc

Printer-friendly Version

Interactive Discussion 
Ginoux, P., Chin, M., Tegen, I., Prospero, J., Holben, B., Dubovik, O., and Lin, S.-J.: Sources and global distributions of dust aerosols simulated with the GOCART model, J. Geophys. Res., 106, 20255-20273, 2001. 448

Goody, R. and Yung, Y.: Atmospheric Radiation: Theoretical Basis, Oxford University Press, 1989. 451

Grainger, R., Peters, D., Thomas, G., Smith, A., Siddan, R., Carboni, E., and Dudhia, A.: Measuring volcanic plume and ash properties from space, Geological Society, London, Special Publications, 380, 293-320, doi:10.1144/SP380.7, 2013. 459, 463

Holben, B., Eck, T., Slutsker, I., Tanre, D., Buis, J., Setzer, A., Vermote, E., Reagan, J., Kaufman, Y., Nakajima, T., Lavenu, F., Jankowiak, I., and Smirnov, A.: AERONET - a federated instrument network and data archive for aerosol characterization, Remote Sens. Environ., 66, 1-16, 1998. 458

Holz, R., Ackerman, S., Antonelli, P., Nagle, F., Knuteson, R., McGill, M., Hvlaka, D., and Hart, W.: An Improvement to the High-Spectral-Resolution $\mathrm{CO}_{2}$-Slicing Cloud-Top Altitude Retrieval, J. Atmos. Ocean. Tech., 23, 653-669, 2006. 448

Hsu, N., Tsay, S.-C., King, M., and Herman, J.: Aerosol properties over bright reflecting source regions, IEEE Geosci. Remote S., 42, 557-569, 2004. 458

IPCC: Climate Change 2007 - The Fourth Assessment Report of the IPCC, Cambridge University Press, 2007. 446

Jethva, H., Torres, O., and Ahn, C.: Global assessment of IMI aerosol single-scattering albedo using ground-based AERONET inversion, J. Geophys. Res., 119, 9020-9040, doi:10.1002/2014JD021672, 2014. 448

Kahn, B., Eldering, A., Clough, S., Fetzer, E., Fishbein, E., Gunson, M., Lee, S.-Y., Lester, P., and Realmuto, V.: Near micron sized cirrus cloud particles in high-resolution infrared spectra: an orographic case study, Geophys. Res. Lett., 30, 1441, doi:10.1029/2003GL016909, 2003. 450

Kirchner, I., Stenchikov, G., Graf, H.-F., Bobock, A., and Antuna, J.: Climate model simulation of winter warming and summer cooling following the 1991 Mount Pinatubo volcanic eruption, J. Geophys. Res., 104, 19039-19055, 1999. 447

30 Klüser, L., Martynenko, D., and Holzer-Popp, T.: Thermal infrared remote sensing of mineral dust over land and ocean: a spectral SVD based retrieval approach for IASI, Atmos. Meas. Tech., 4, 757-773, doi:10.5194/amt-4-757-2011, 2011. 450

\section{AMTD}

$8,443-485,2015$

\section{Dust height using AIRS/MODIS synergy}

S. DeSouza-Machado et al.

\section{Title Page}

Abstract Introduction

Conclusions References

Tables Figures

14

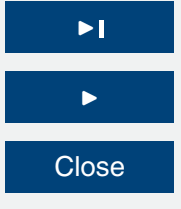

Full Screen / Esc

Printer-friendly Version

Interactive Discussion 
Koren, I., Kaufman, Y., Washington, R., Todd, M., Rudich, Y., Martins, J., and Rosenfeld, D.: The Bodele depression: a single spot in the Sahara that provides most of the mineral dust to the Amazon forest, Environ. Res. Lett., 1, 014005, doi:10.1088/1748-9326/1/1/014005, 2006. 446

5 Levy, R. C., Mattoo, S., Munchak, L. A., Remer, L. A., Sayer, A. M., Patadia, F., and Hsu, N. C.: The Collection 6 MODIS aerosol products over land and ocean, Atmos. Meas. Tech., 6, 2989-3034, doi:10.5194/amt-6-2989-2013, 2013. 463

Liou, K.-N.: An Introduction to Atmospheric Radiation, Elsevier Press, 2002. 451

Maddy, E., DeSouza-Machado, S., Nalli, N., Barnet, C., Strow, L., Wolf, W., Xie, H., Gambacorta, A., King, T., Joseph, E., Morris, V., Hannon, S., and Chou, P.: On the effect of dust aerosols on AIRS and IASI operational level 2 products, Geophys. Res. Lett., 39, L10809, doi:10.1029/2012GL052070, 2012. 446

Masuda, K., Takashima, T., and Takayama, Y.: Emissivity of pure and sea waters for the model sea surface in the infrared window regions, Remote Sens. Environ., 24, 313-329, 1988. 452

Perez, C., Nicovic, S., Pejanovic, G., Baldasano, J.-M., and Ozsoy, E.: Interactive dustradiation modeling: A step to improve weather forecasts, J. Geophys. Res., 111, D16206, doi:10.1029/2005JD006717, 2006. 446

Pierangelo, C., Chédin, A., Heilliette, S., Jacquinet-Husson, N., and Armante, R.: Dust altitude and infrared optical depth from AIRS, Atmos. Chem. Phys., 4, 1813-1822, doi:10.5194/acp4-1813-2004, 2004. 448

Platnick, S., King, M., Ackerman, S., Menzel, W., Baum, B., Riedi, J., and Frey, R.: The MODIS cloud products: algorithms and examples from Terra, IEEE T. Geosci. Remote, 41, 459-473, doi:10.1109/TGRS.2002.808301, 2003. 447

Pollack, J., Koon, O. B., and Khare, B.: Optical properties of some terrestrial rocks and glasses, ICARUS, 19, 372-389, 1973. 452

Remer, L., Kaufman, Y., Tanré, D., Mattoo, S., Chu, D. A., Martins, J., Li, R.-R., Ichoku, C., Levy, R., Kleidman, R., Eck, T., Vermote, E., and Holben, H.: The MODIS aerosol algorithm, products and validation, J. Atmos. Sci., 62, 947-973, 2005. 447, 457

Rodgers, C.: Inverse Methods for Atmospheric Sounding, World Scientific, Singapore, 2000. 466

Sayer, A. M., Poulsen, C. A., Arnold, C., Campmany, E., Dean, S., Ewen, G. B. L., Grainger, R. G., Lawrence, B. N., Siddans, R., Thomas, G. E., and Watts, P. D.: Global
AMTD

8, 443-485, 2015

\section{Dust height using AIRS/MODIS synergy}

S. DeSouza-Machado et al.

\section{Title Page}

Abstract Introduction

Conclusions References

Tables Figures

14

4

Back

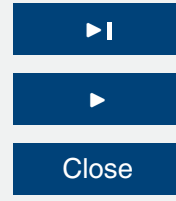

Full Screen / Esc

Printer-friendly Version

Interactive Discussion 
retrieval of ATSR cloud parameters and evaluation (GRAPE): dataset assessment, Atmos. Chem. Phys., 11, 3913-3936, doi:10.5194/acp-11-3913-2011, 2011. 459

Shi, Y., Zhang, J., Reid, J. S., Hyer, E. J., and Hsu, N. C.: Critical evaluation of the MODIS Deep Blue aerosol optical depth product for data assimilation over North Africa, Atmos. Meas. Tech., 6, 949-969, doi:10.5194/amt-6-949-2013, 2013. 462

Stenchikov, G., Kirchner, I., Bobock, A., Graf, H.-F., Antuna, J., Grainger, R., Lambert, A., and Thomason, L.: Radiative forcing from the 1991 Mount Pinatubo volcanic eruption, J. Geophys. Res., 103, 13837-13857, 1998. 447

Strow, L., Hannon, S., DeSouza-Machado, S., Tobin, D., and Motteler, H.: An overview of the AIRS radiative transfer model, IEEE T. Geosci. Remote, 41, 303-313, 2003. 449

Torres, O., Tanskanen, A., Veihelmann, B., Ahn, C., Braak, R., Bhartia, P., Veefkind, P., and Levelt, P.: Aerosols and surface UV products from OMI observations: an overview, J. Geophys. Res., 103, D24S47, doi:10.1029/2007JD008809, 2007. 448

Torres, O., Ahn, C., and Chen, Z.: Improvements to the OMI near-UV aerosol algorithm using A15 train CALIOP and AIRS observations, Atmos. Meas. Tech., 6, 3257-3270, doi:10.5194/amt6-3257-2013, 2013. 459, 460

Vandenbussche, S., Kochenova, S., Vandaele, A. C., Kumps, N., and De Mazière, M.: Retrieval of desert dust aerosol vertical profiles from IASI measurements in the TIR atmospheric window, Atmos. Meas. Tech., 6, 2577-2591, doi:10.5194/amt-6-2577-2013, 2013. 448, 450

Volz, F.: Infrared optical constants of ammonium sulphate, Sahara Dust, volcanic pumice and flash, Appl. Optics, 12, 564-568, 1973. 452

Winker, D. M., Hunt, W., and Hostetler, C.: Status and performance of the CALIOP lidar, Proc. SPIE, 5575, 8-15, 2004. 458

Winker, D. M., Vaughan, M. A., Omar, A., Hu, Y., Powell, K. A., Liu, Z., Hunt, W. H., and Young, S. A.: Overview of the CALIPSO mission and CALIOP data processing algorithms, J. Atmos. Ocean. Tech., 26, 2310-2323, doi:10.1175/2009JTECHA1281.1, 2009. 458

Yue, Q. and Liou, K.-N.: Cirrus cloud optical and microphysical properties deyeremined from AIRS infrared spectra, Geophys. Res. Lett., 36, L05810, doi:10.1029/2008GL036502, 2009. 450

\section{AMTD}

$8,443-485,2015$

\section{Dust height using AIRS/MODIS synergy}

S. DeSouza-Machado et al.

\section{Title Page}

Abstract Introduction

Conclusions References

Tables Figures

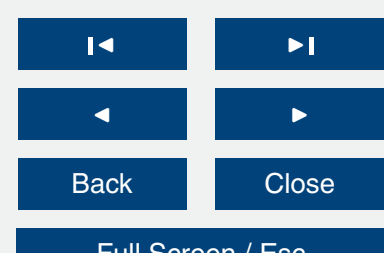

Full Screen / Esc

Printer-friendly Version

Interactive Discussion 
Table 1. Pearson Correlation $R$ against CALIOP heights, computed over months of July 2006December 2008.

\begin{tabular}{lrrr}
\hline REGION & GOCART & MODIS/AIRS & $\chi^{2}$-AIRS \\
\hline Atlantic & 0.16 & 0.88 & 0.90 \\
Pacific & 0.72 & 0.54 & 0.61 \\
Mediterranean & 0.25 & 0.82 & 0.22 \\
Asia/Africa & -0.07 & -0.02 & 0.30 \\
\hline
\end{tabular}

$8,443-485,2015$

Dust height using AIRS/MODIS synergy

S. DeSouza-Machado et al.

Title Page

\begin{tabular}{|c|c|}
\hline Abstract & Introduction \\
\hline Conclusions & References \\
\hline Tables & Figures \\
\hline I4 & $\checkmark \mathbf{I}$ \\
\hline 4 & $\triangleright$ \\
\hline Back & Close \\
\hline Full Screen / Esc \\
\hline
\end{tabular}

Printer-friendly Version

Interactive Discussion 
Table 2. Mean (left) and standard deviation (right) of heights averaged over months of 20062009 (in km).

\begin{tabular}{lcccccccc}
\hline REGION & GOCART & MODIS/AIRS & $\chi^{2}$-AIRS & CALIOP & GOCART & MODIS/AIRS & $\chi^{2}$-AIRS & CALIOP \\
\hline Atlantic & 3.09 & 3.11 & 3.04 & 3.08 & 0.42 & 0.61 & 1.07 & 0.46 \\
Pacific & 4.62 & 3.49 & 3.42 & 2.93 & 0.17 & 1.06 & 1.40 & 0.88 \\
Mediterranean & 3.07 & 2.76 & 2.99 & 3.00 & 0.52 & 0.82 & 1.34 & 0.46 \\
Asia/Africa & 2.53 & 2.68 & 3.65 & 3.31 & 0.48 & 1.37 & 1.71 & 0.61 \\
\hline
\end{tabular}

AMTD

$8,443-485,2015$

Dust height using AIRS/MODIS synergy

S. DeSouza-Machado et al.

\section{Title Page}

Abstract

Introduction

Conclusions

References

Tables

Figures

14

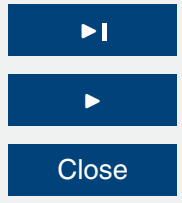

Back

Close

Full Screen / Esc

Printer-friendly Version

Interactive Discussion

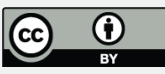




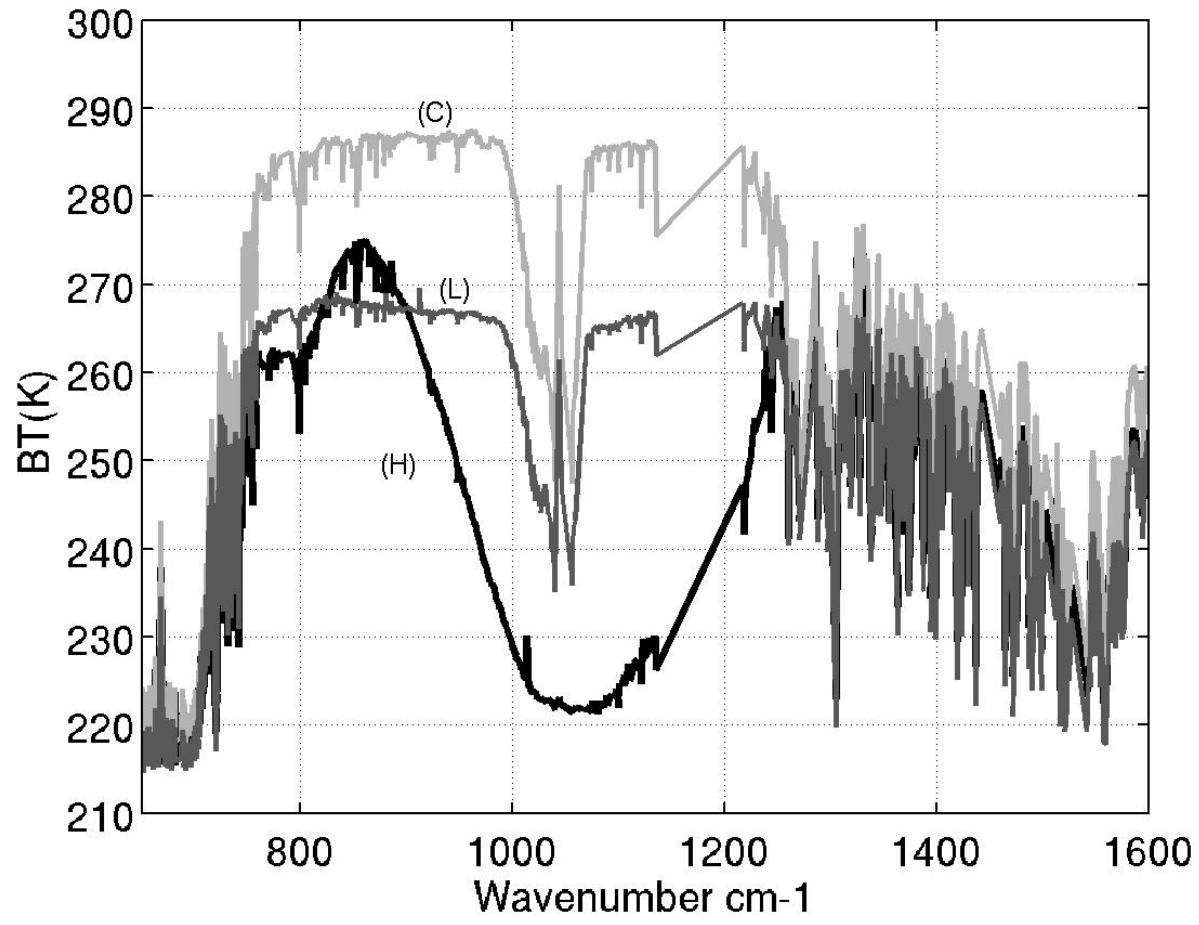

Figure 1. AIRS spectra obtained at three locations on 6 June 2011 over S. America and the southern Atlantic Ocean. $(\mathrm{H})$ in black is very close to the Puyehue-Calderon volcano, $(\mathrm{L})$ in dark gray is from the ash plume that has drifted thousands of kilometers over the Atlantic while (C) in light gray is from a clear scene over ocean.
AMTD

$8,443-485,2015$

Dust height using AIRS/MODIS synergy

S. DeSouza-Machado et al.

\section{Title Page}

\section{Abstract}

Introduction

Conclusions

References

Tables

Figures

14

4

Back

Full Screen / Esc

Printer-friendly Version

Interactive Discussion 

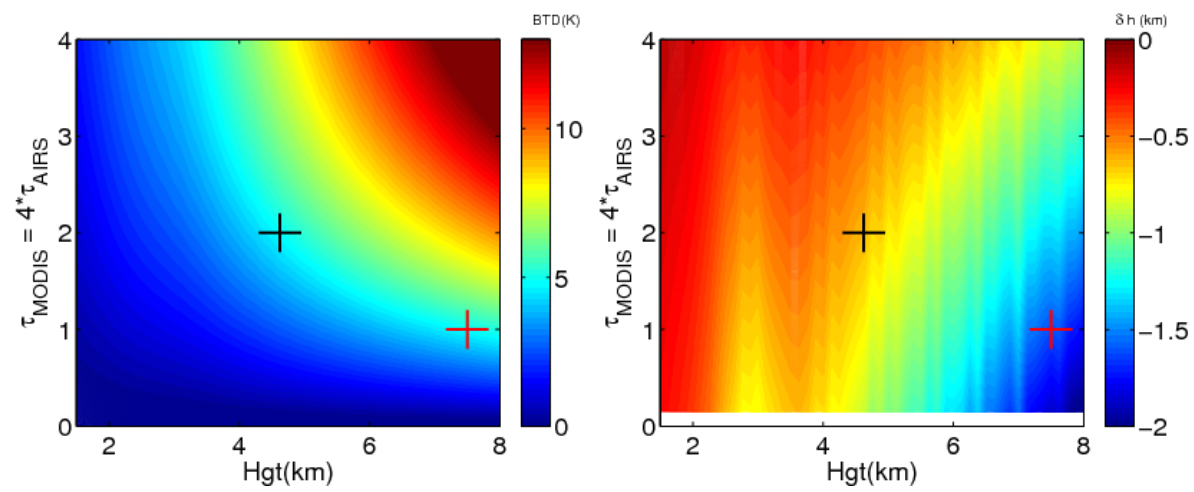

Figure 2. Sensitivity of retrieved heights, using a tropical profile. Left panel shows how $\mathrm{BTD}=\mathrm{BT} 1231-\mathrm{BT} 961$ varies as a function of height $(\mathrm{km})$ and MODIS AOD, where we use $\tau_{\text {MODIS }}=4 \tau_{\text {AIRS }}$. The right panel show this translates to an uncertainty in retrieved height for an uncertainty $\delta f=+1$, again as a function of height $(\mathrm{km})$ and MODIS AOD. The largest uncertainties are at the lower optical depths (where it is difficult to distinguish from clear sky scenes) and high altitudes (where a small change in loading can produce large changes in BTD).
AMTD

8, 443-485, 2015

Dust height using AIRS/MODIS synergy

S. DeSouza-Machado

et al.

\section{Title Page}

\section{Abstract}

Introduction

Conclusions

References

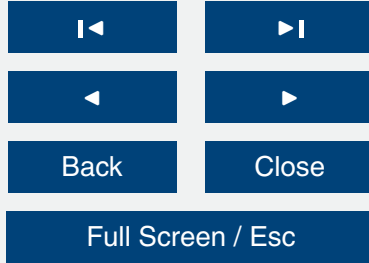

Printer-friendly Version

Interactive Discussion 

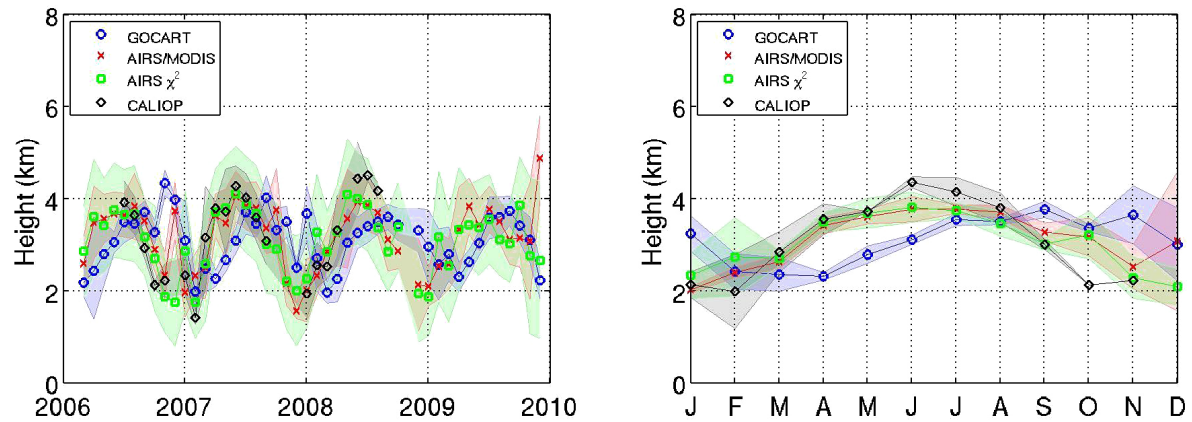

AMTD

8, 443-485, 2015

Dust height using AIRS/MODIS synergy

S. DeSouza-Machado et al.

Title Page

Abstract

Introduction

Conclusions

References

Tables

Figures

Figure 3. AIRS retrieved heights compared to CALIOP mean aerosol heights, over the period 2006-2009. CALIOP data is available starting July 2006. In this plot the Atlantic region is considered. Blue is the GOCART climatology, red/green are the MODIS-based and $\chi^{2}$-based AIRS retrievals, while black is the CALIOP data. Left panel: 2006-2009 seasonal cycle; right panel: monthly averages.

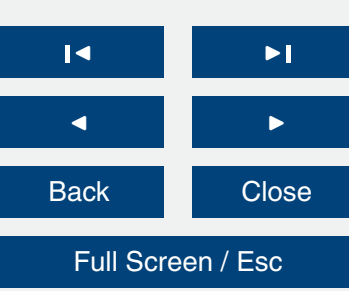

Printer-friendly Version

Interactive Discussion 

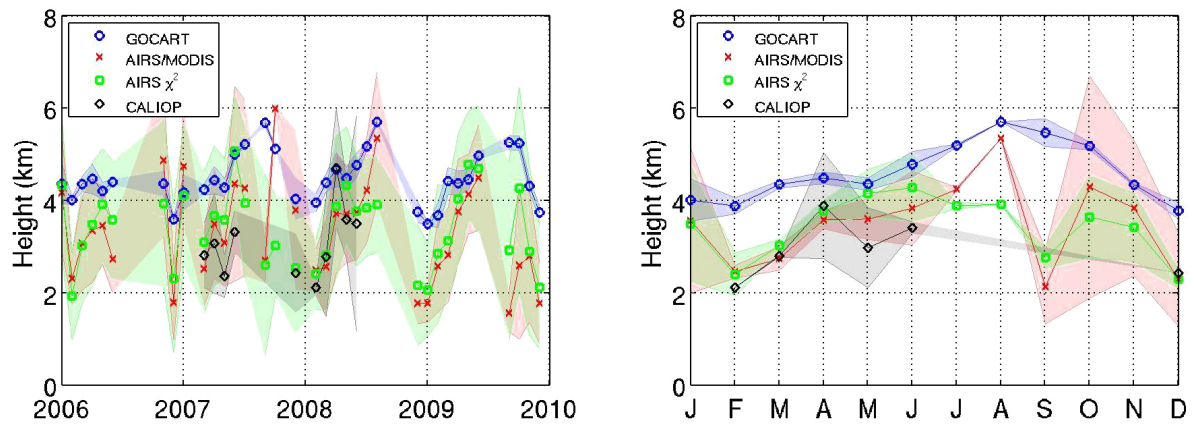

AMTD

$8,443-485,2015$

\section{Dust height using AIRS/MODIS synergy}

\section{S. DeSouza-Machado et al.}

\section{Title Page}

\section{Abstract}

Introduction

Conclusions

References

Tables

Figures

Figure 4. AIRS retrieved heights compared to CALIOP mean aerosol heights, over the period 2006-2009. CALIOP data is available starting July 2006. In this plot the Pacific region is considered. Blue is the GOCART climatology, red/green are the MODIS-based and $\chi^{2}$-based AIRS retrievals, while black is the CALIOP data. Left panel: 2006-2009 seasonal cycle; right panel: monthly averages.

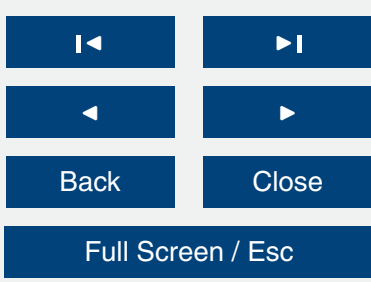

Printer-friendly Version

Interactive Discussion 

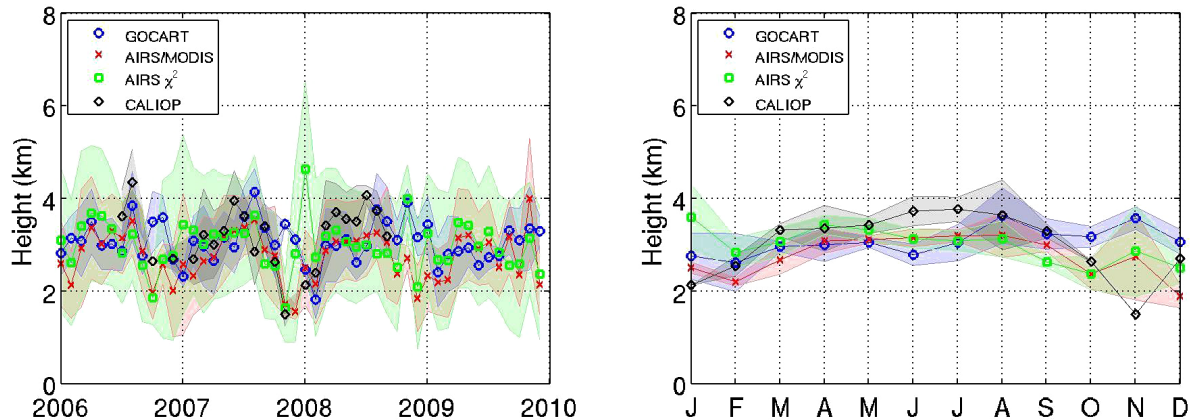

Figure 5. AIRS retrieved heights compared to CALIOP mean aerosol heights, over the period 2006-2009. CALIOP data is available starting July 2006. In this plot the Mediterranean region is considered. Blue is the GOCART climatology, red/green are the MODIS-based and $\chi^{2}$-based AIRS retrievals, while black is the CALIOP data. Left panel: 2006-2009 seasonal cycle; right panel: monthly averages.
AMTD

8, 443-485, 2015

\section{Dust height using} AIRS/MODIS synergy

\section{S. DeSouza-Machado}

et al.

\section{Title Page}

\section{Abstract}

Introduction

Conclusions

References

Tables

Figures

14

4

Back

Full Screen / Esc

Printer-friendly Version

Interactive Discussion 

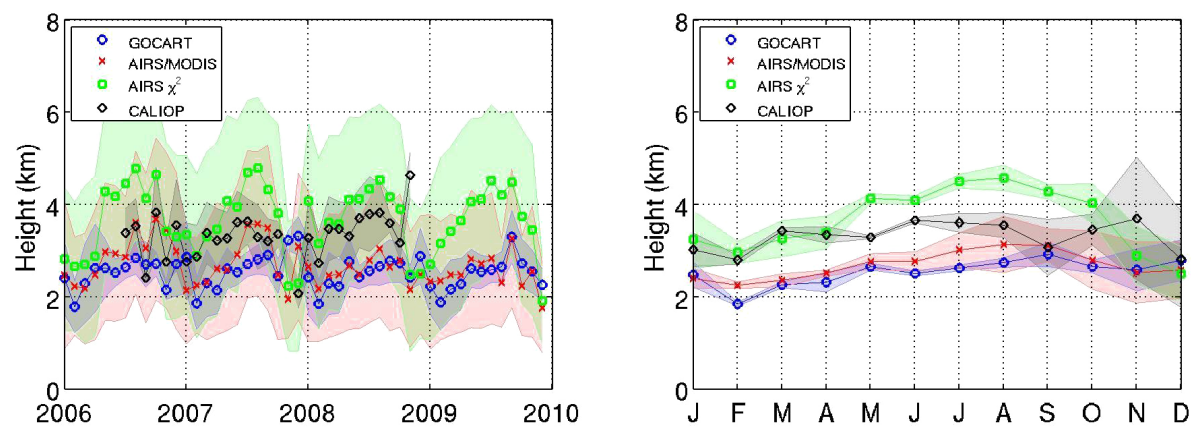

\section{AMTD}

8, 443-485, 2015

\section{Dust height using AIRS/MODIS synergy}

\section{S. DeSouza-Machado et al.}

\section{Title Page}

\section{Abstract}

Introduction

Conclusions

References

Tables

Figures

Figure 6. AIRS retrieved heights compared to CALIOP mean aerosol heights, over the period 2006-2009. CALIOP data is available starting July 2006. In this plot the Asia/Africa landmass region is considered. Blue is the GOCART climatology, red/green are the MODIS-based and $\chi^{2}$-based AIRS retrievals, while black is the CALIOP data. Left panel: 2006-2009 seasonal cycle; right panel: monthly averages.

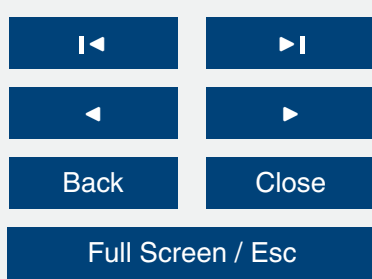

Printer-friendly Version

Interactive Discussion 


\section{AATSR HGTS}

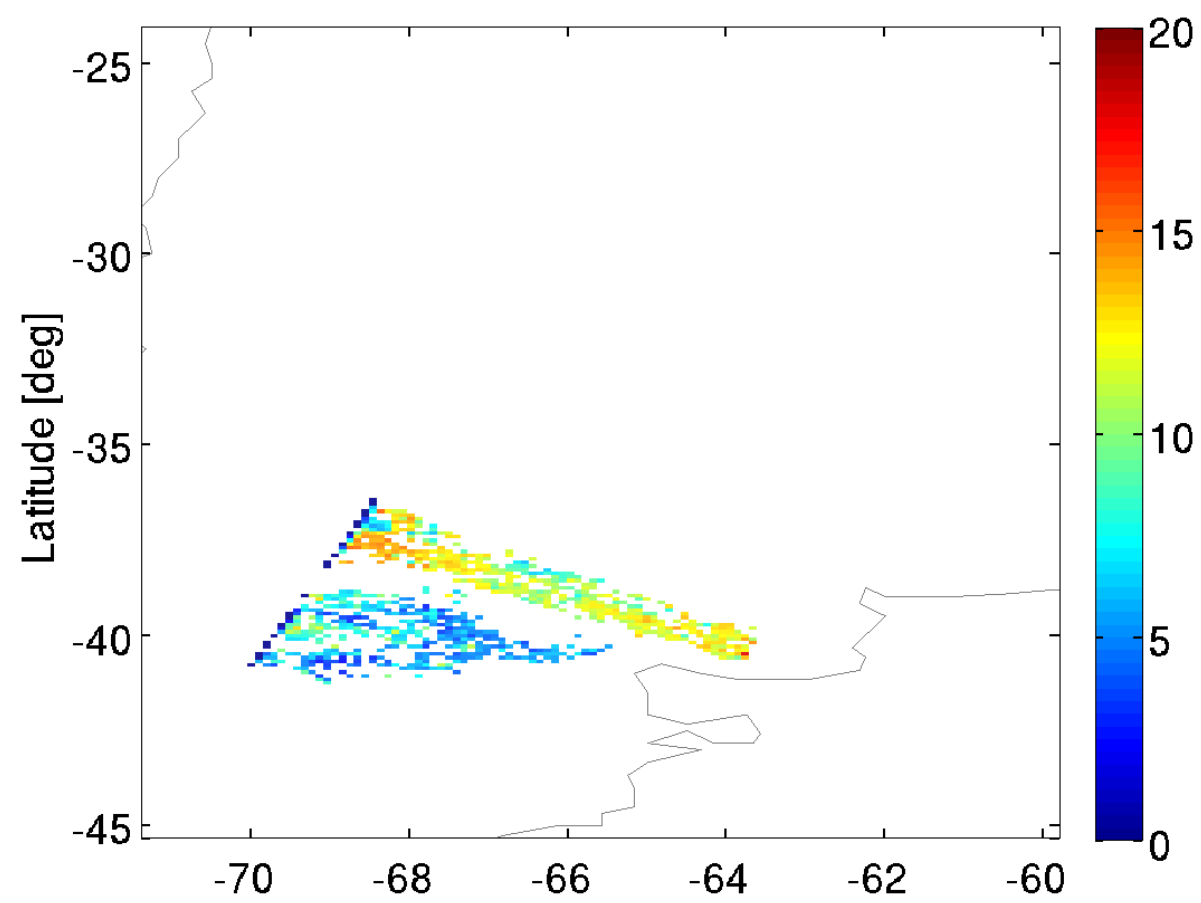

Figure 7. AATSR height retrievals for 6 June 2011. One sees two plumes over the S. American continent, one having a mean height of about $6 \mathrm{~km}$ and the other having a mean height of about $12 \mathrm{~km}$.

\section{AMTD}

$8,443-485,2015$

Dust height using AIRS/MODIS synergy

S. DeSouza-Machado et al.

\section{Title Page}

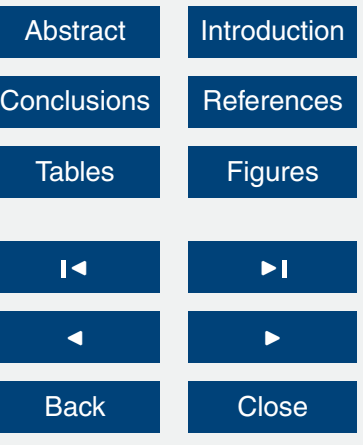

Full Screen / Esc

Printer-friendly Version

Interactive Discussion 


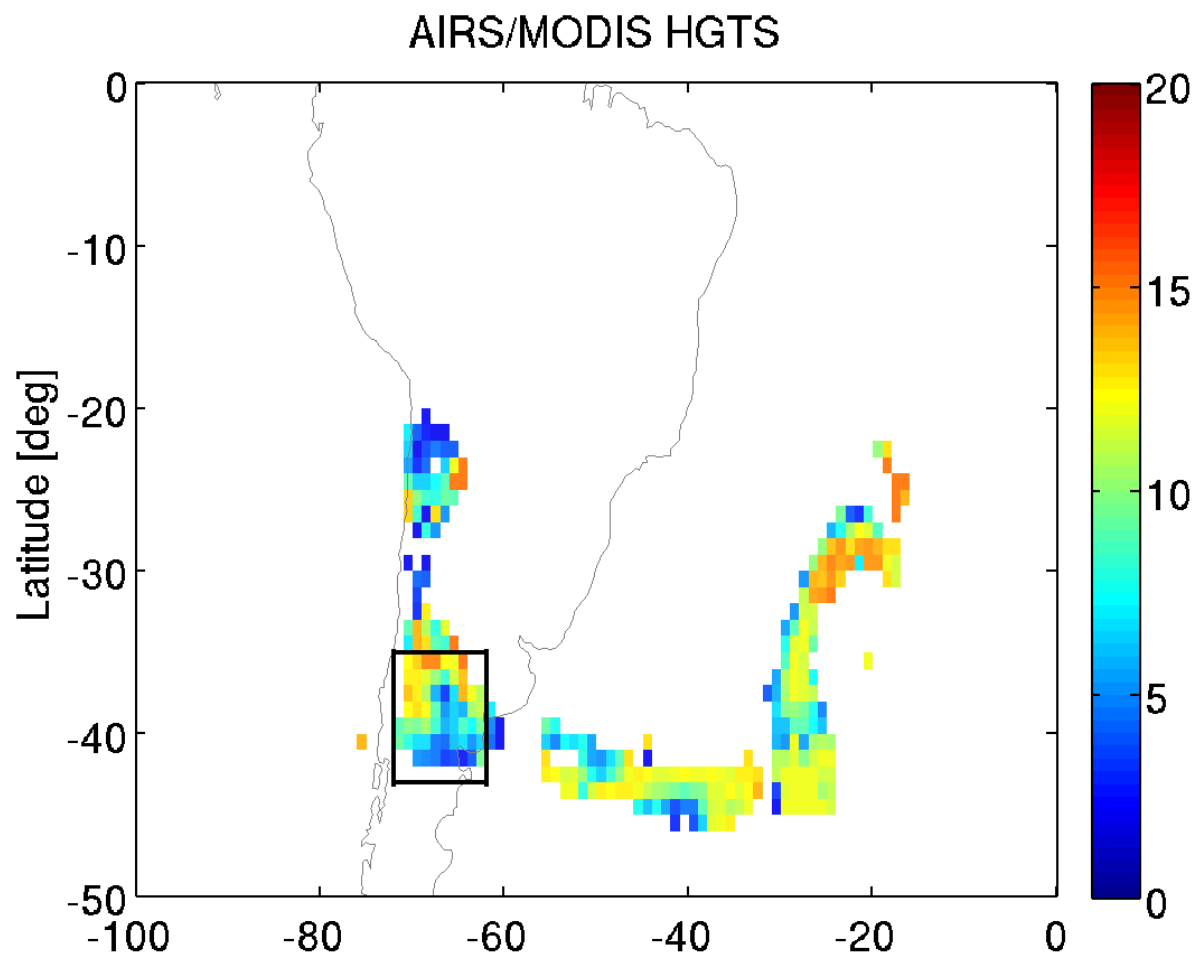

Figure 8. AIRS height retrievals for 6 June 2011, based on constraints using MODIS data. One sees the ash plumes have already been blown over the $\mathrm{S}$. Atlantic. The black box shows the AASTR data coverage, as displayed in Fig. 7.

\section{AMTD}

$8,443-485,2015$

Dust height using AIRS/MODIS synergy

S. DeSouza-Machado

et al.

\section{Title Page}

Abstract

Introduction

Conclusions

References

Tables

Figures

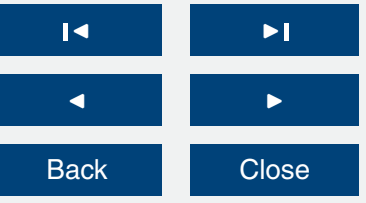

Full Screen / Esc

Printer-friendly Version

Interactive Discussion 


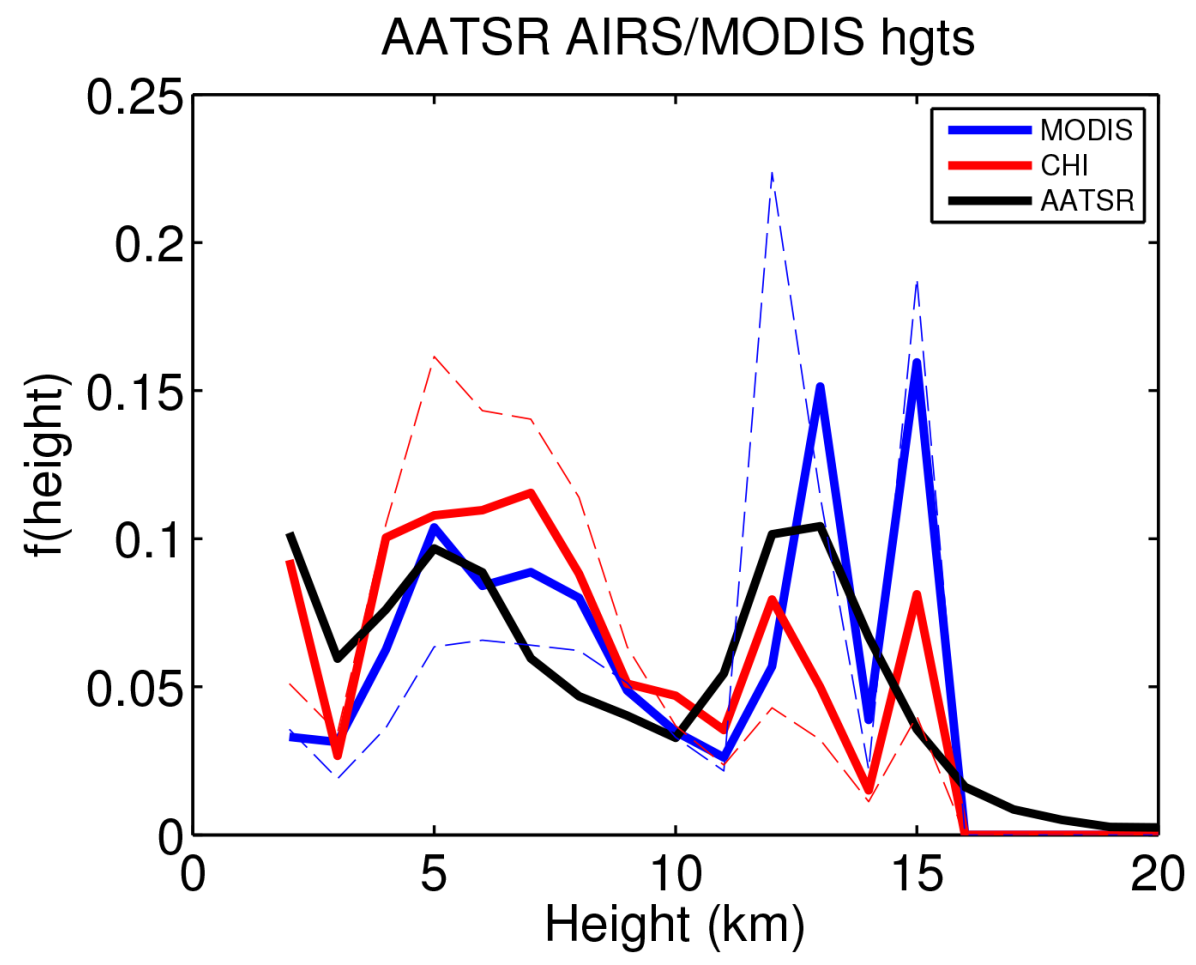

AMTD

8, 443-485, 2015

Dust height using AIRS/MODIS synergy

S. DeSouza-Machado

et al.

Title Page

Abstract

Introduction

Conclusions

References

Tables

Figures

14

4

Back

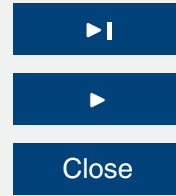

Full Screen / Esc

Figure 9. AIRS vs. AATSR height retrievals for 6 June 2011, compared using pdfs. The thick curves are for the "co-located" heights, which in this case would be mostly over land - the black curve is for the AATSR heights, the blue curve is the MODIS based AIRS height retrieval while the red curve is the $\chi^{2}$ based retrieval. The dashed blue and red curves shows the corresponding histograms when all AIRS retrieved heights are used.

Printer-friendly Version

Interactive Discussion 


\section{AIRS/MODIS HGTS}

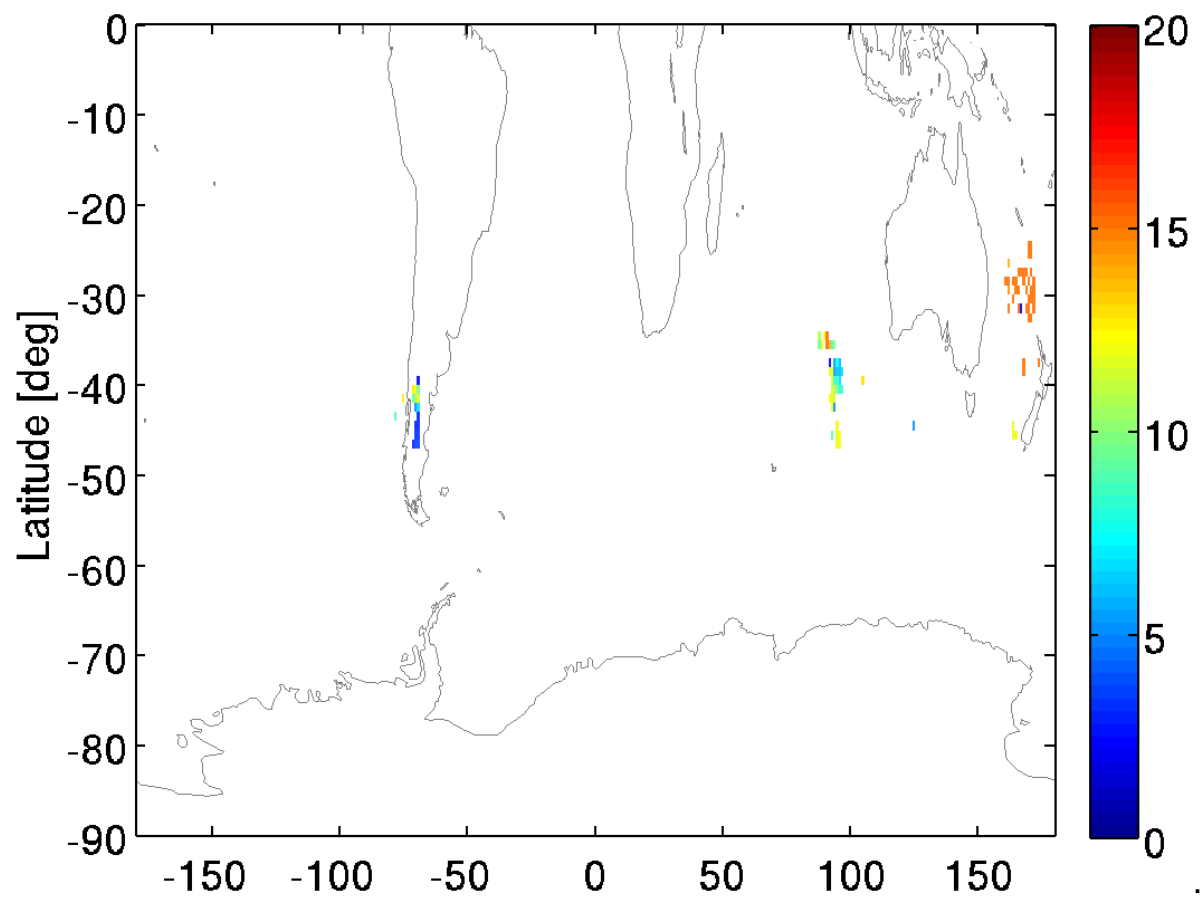

Figure 10. AIRS height retrievals for 11 June 2011, based on constraints using MODIS data. One sees some of the ash plumes is already near Australia; in fact some of the ash has already traveled around the hemisphere back to the S. American continent.

\section{AMTD}

$8,443-485,2015$

Dust height using AIRS/MODIS synergy

S. DeSouza-Machado et al.

\section{Title Page}

Abstract

Introduction

Conclusions

References

Tables

Figures

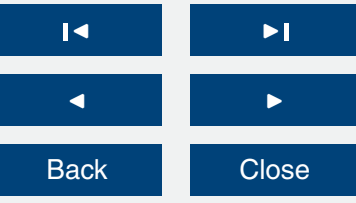

Full Screen / Esc

Printer-friendly Version

Interactive Discussion 


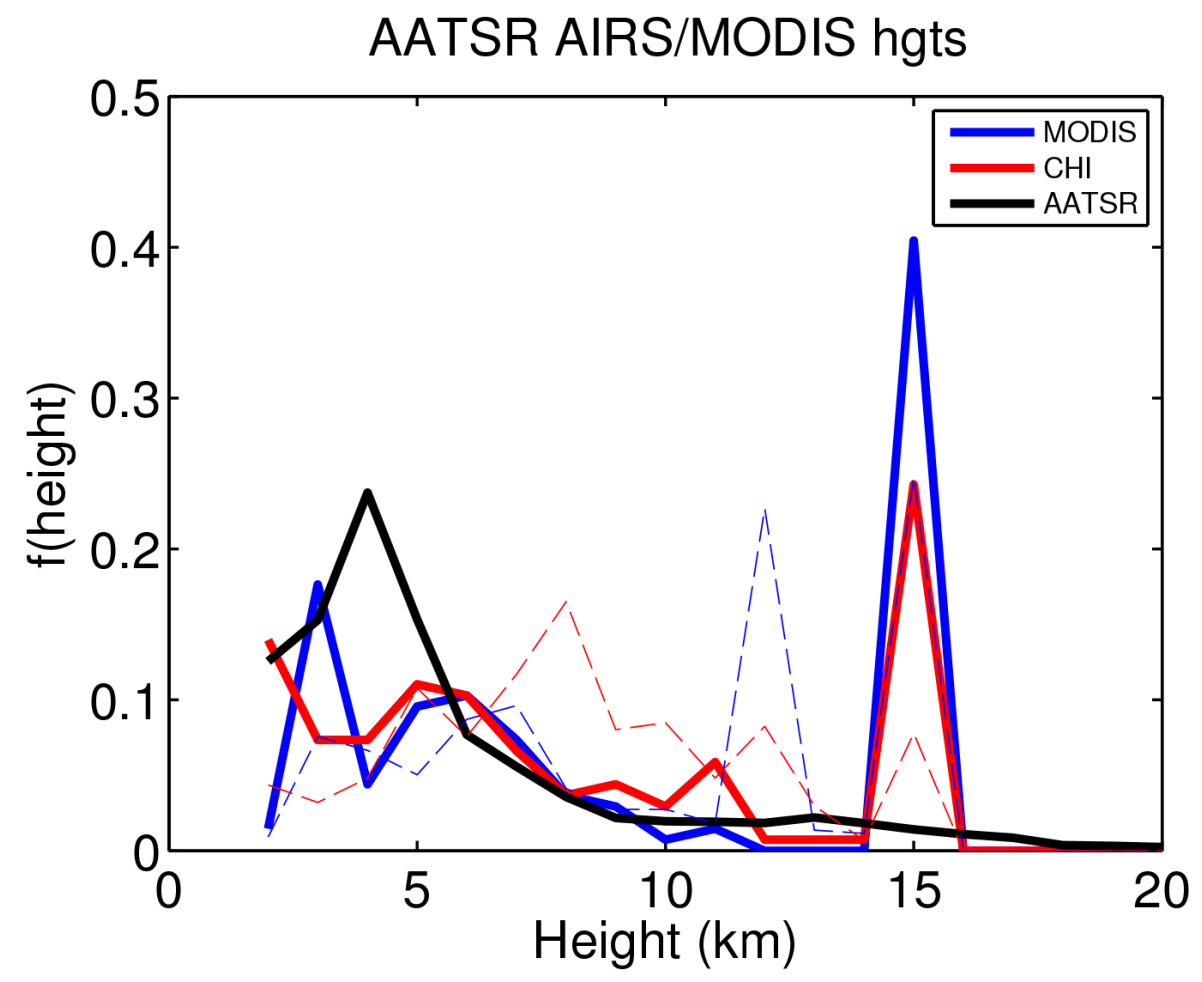

Figure 11. AIRS vs. AATSR height retrievals for 11 June 2011, compared using pdfs. As in Fig. 9, the thick curves are for the "co-located" heights, which in this case would be mostly over land - the black curve is for the AATSR heights, the blue curve is the MODIS based AIRS height retrieval while the red curve is the $\chi^{2}$ based retrieval. The dashed blue and red curves shows the corresponding histograms when all AIRS retrieved heights are used. The AATSR data was located mostly over the S. American continent, and the histogram shows a peak at about $5 \mathrm{~km}$. The AIRS data also showed some high altitude $(15 \mathrm{~km})$ ash had circumvented the globe; the dashed curves for the AIRS retrieved heights are for ash that is close to Australia.
AMTD

$8,443-485,2015$

\section{Dust height using} AIRS/MODIS synergy

\section{S. DeSouza-Machado} et al.

\section{Title Page}

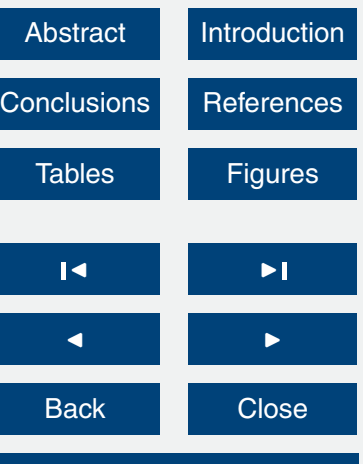

Full Screen / Esc

Printer-friendly Version

Interactive Discussion 
NOAA HYSPLIT MODEL

Forward trajectories starting at 0600 UTC 05 Jun 11

CDC1 Meteorological Data

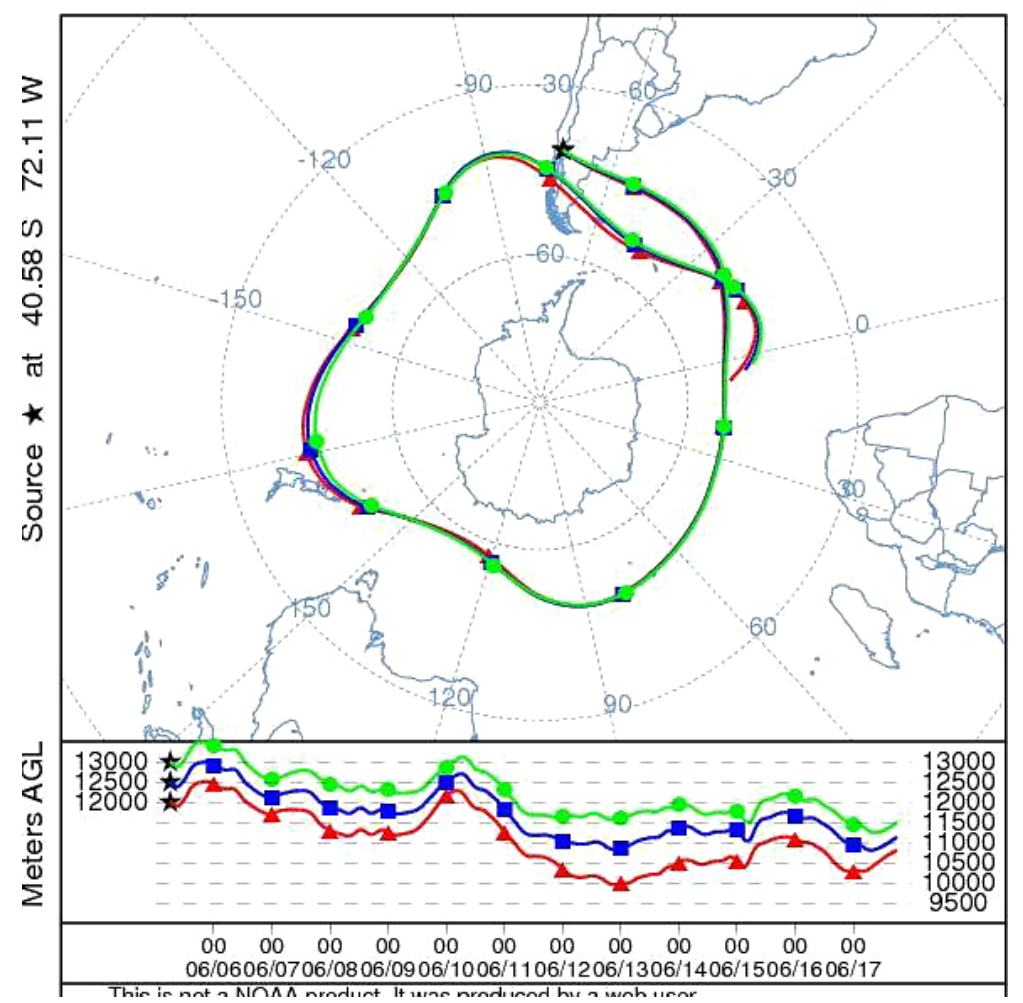

Figure 12. NOAA HYSPLIT model for 5-15 June 2011, showing the evolution of air masses at different heights during this time period. It is seen the $12 \mathrm{~km}$ air mass remained relatively stable, descending about $2 \mathrm{~km}$ in 10 days.

\section{AMTD}

$8,443-485,2015$

\section{Dust height using} AIRS/MODIS synergy

S. DeSouza-Machado et al.

\section{Title Page}

\section{Abstract}

Introduction

Conclusions

References

Tables

Figures

\begin{tabular}{|c|c|}
\hline I4 & $>$ I \\
\hline 4 & $\bullet$ \\
\hline Back & Close \\
\hline Full Screen / Esc
\end{tabular}

Printer-friendly Version

Interactive Discussion 